\title{
Worldwide Incidence and Prevalence of Neuromyelitis Optica
}

\section{A Systematic Review}

Viktoria Papp, MD, PhD, Melinda Magyari, MD, PhD, Orhan Aktas, MD, Thomas Berger, MD, Simon A. Broadley, MD, PhD, Philippe Cabre, MD, Anu Jacob, MD, Jun-ichi Kira, MD, PhD, Maria Isabel Leite, MD, DPhil, Romain Marignier, MD, PhD, Katsuichi Miyamoto, MD, PhD, Jacqueline Palace, MD, Albert Saiz, MD, PhD, Maria Sepulveda, MD, Olafur Sveinsson, MD, PhD, and Zsolt Illes, MD, PhD

Neurology ${ }^{\circledR}$ 2021;96:59-77. doi:10.1212/WNL.0000000000011153

\section{Abstract \\ Objective}

Since the last epidemiologic review of neuromyelitis optica/neuromyelitis optica spectrum disorder (NMO/NMOSD), 22 additional studies have been conducted. We systematically review the worldwide prevalence, incidence, and basic demographic characteristics of NMOSD and provide a critical overview of studies.

\section{Methods}

PubMed, Ovid MEDLINE, and Embase using Medical Subject Headings and keyword search terms and reference lists of retrieved articles were searched from 1999 until August 2019. We collected data on the country; region; methods of case assessment and aquaporin-4 antibody (AQP4-Ab) test; study period; limitations; incidence (per 100,000 person-years); prevalence (per 100,000 persons); and age-, sex-, and ethnic group-specific incidence or prevalence.

\section{Results}

We identified 33 relevant articles. The results indicated the highest estimates of incidence and prevalence of NMOSD in Afro-Caribbean region (0.73/100 000 person-years [95\% CI: 0.45-1.01] and 10/100 000 persons [95\% CI: 6.8-13.2]). The lowest incidence and prevalence of NMOSD were found in Australia and New Zealand (0.037/100 000 person-years [95\% CI: 0.036-0.038] and $0.7 / 100,000$ persons [95\% CI: $0.66-0.74]$ ). There was prominent female predominance in adults and the AQP4-Ab-seropositive subpopulation. The incidence and prevalence peaked in middleaged adults. African ethnicity had the highest incidence and prevalence of NMOSD, whereas White ethnicity had the lowest. No remarkable trend of incidence was described over time.

\section{Conclusion}

NMOSD is a rare disease worldwide. Variations in prevalence and incidence have been described among different geographic areas and ethnicities. These are only partially explained by different study methods and NMO/NMOSD definitions, highlighting the need for specifically designed epidemiologic studies to identify genetic effects and etiologic factors.

\author{
Correspondence \\ Dr. Illes \\ zsolt.illes@rsyd.dk
}

\section{ค Podcast}

Dr. Stacey Clardy interviews Dr. Zsolt Illes about the worldwide impact of neuromyelitis optica.

NPub.org/e52wrv 


\section{Glossary}

AQP4-Ab = aquaporin-4 antibody; CBA = cell-based assay; IPND = International Panel for NMO Diagnosis; NMO = neuromyelitis optica; NMOSD = neuromyelitis optica spectrum disorder; $\mathbf{M O G}=$ myelin oligodendrocyte glycoprotein; $\mathbf{O N}=$ optic neuritis; $\mathbf{T M}=$ transverse myelitis.

Neuromyelitis optica (NMO) is an antibody-mediated inflammatory disease of the CNS. The understanding of the disease has evolved extensively through the last $100-125$ years. ${ }^{1}$ In 2005, the discovery of specific antibodies against the aquaporin-4 (AQP4) water channel in patients with NMO enabled the distinction of NMO from MS and resulted in the 2006 Wingerchuk criteria. ${ }^{2,3}$ The introduction of the cell-based assay (CBA) to search for AQP4 antibody (AQP4-Ab) and improvements of test sensitivity allowed the recognition of additional syndromes associated with AQP4-Ab named as neuromyelitis optica spectrum disorders (NMOSDs). ${ }^{4}$ The 2015 International Panel for NMO Diagnosis (IPND) criteria united the NMO and NMOSD definitions, proposed a categorization by stratifying for $\mathrm{AQP} 4-\mathrm{Ab}$ serostatus, and recommend the use of CBA owing to highest sensitivity $(76.7 \%)$ and specificity $(99.8 \%){ }^{1}$

The cause of the disease is not fully understood. ${ }^{5,6}$ Wellestablished epidemiologic studies can generate hypotheses and thereby contribute to the identification of potential risk factors and essential features of disease etiology.

The last review of the incidence and prevalence of NMO/ NMOSD was published in 2015, when 7 population-based studies were available. ${ }^{7}$ Since then, 22 additional epidemiologic studies have been published using also the 2015 criteria, and these may improve our understanding of the NMOSD epidemiology. Here, we provide a critical overview of studies reporting the incidence and prevalence of NMO/NMOSD from around the world and discuss the challenges of such epidemiologic studies.

\section{Methods}

We performed a systematic search in PubMed, Ovid MEDLINE, and Embase databases for epidemiologic studies in NMO/NMOSD published from 1999 to August 2019 (figure, supplementary file, doi.org/10.5061/dryad.prr4xgxh9). Two authors (V.P. and Z.I.) independently assessed whether the identified abstracts met the inclusion criteria: (1) NMO/ NMOSD; (2) original data; (3) incidence or prevalence of NMO/NMOSD; and (4) available English abstract. Furthermore, we searched the reference lists of review articles and the relevant publications for additional studies. If either reviewer selected an abstract, it underwent independent full-text review by the 2 reviewers. Disagreements were resolved by consensus. We excluded review articles, conference proceedings, and abstracts due to limited data on study design for critical review.

We collected data on the country, region, size of source population, case ascertainment, applied diagnostic criteria and antibody test method, observation period of incidence, definition of incident event, limitations, incidence (100,000 person-years), prevalence $(100,000$ persons) and age-, sex-, or ethnic groupspecific incidence or prevalence, and basic demographic data (tables 1-6, supplementary tables 1-3, doi.org/10.5061/dryad. prr4xgxh9). The review follows Preferred Reporting Items for Systematic Reviews and Meta-Analyses (PRISMA) guideline.

\section{Results}

\section{Search Strategy}

From PubMed, Ovid MEDLINE, and Embase, we identified 664 unique references (figure). We selected 51 articles for fulltext review based on relevant abstracts. Of these, we excluded 1 for not including original data and 17 for not providing the incidence and/or prevalence estimates of NMO/NMOSD. Ultimately, 33 articles met the inclusion criteria.

\section{Study Characteristics}

The number of epidemiologic data of NMO/NMOSD has remained low. All studies are retrospective (tables 1,2 , and 4). The timing of the study may influence the prevalence and incidence estimates due to several changes in the definition of NMO and NMOSD diagnostic criteria and antibody test method in the last decades. ${ }^{1,3,4,8,9}$ Diversity can also be seen in population sample size (varying from $145,979^{10}$ to 130 million $^{11}$ ), study design (cohort study $^{10,12-31}$ or cross-sectional study ${ }^{11,32-41}$; clinicalbased $^{10,12-16,18,19,31,32,37-39,42}$ or survey study $\left.{ }^{11,17,22,35,41}\right)$, case ascertainment (accepting the reported cases $\mathrm{s}^{20,27,34}$ or validating each

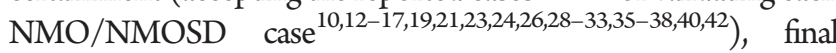
number of cases calculate by statistical analysis, ${ }^{11,18,22,41}$ and AQP4-Ab test (IF-tissue assay, immunoprecipitation, ELISA, and CBA (tables 1,2, and 4). The overall number of samples tested for AQP4-Ab was reported in 5 studies (supplementary table 3, doi. org/10.5061/dryad.prr4xgxh9).

Four nationwide studies involved solely pediatric populations, ${ }^{28-30,41}$ and 3 of these investigated the epidemiology of acquired demyelinating syndromes, not specifically NMO/ NMOSD. ${ }^{28,29,41}$ Three studies applied the 2006 criteria to calculate the prevalence ${ }^{41}$ or incidence ${ }^{28,29}$ of NMO, and 1 used the 2015 IPND criteria for incidence assessment. ${ }^{30}$ Five studies selectively evaluated the adult population. ${ }^{12,15,17,22,23,31}$ The majority of the reports encompassed all ages, $10,11,13,14,16,18-21,24,26,27,32,33,35-38,40$ but some did not recognize any patients with pediatric disease onset (tables 1-4). ${ }^{19,33,37}$

Thirteen of the 33 included studies provided inadequate descriptions of study design, case assessment, or type of 


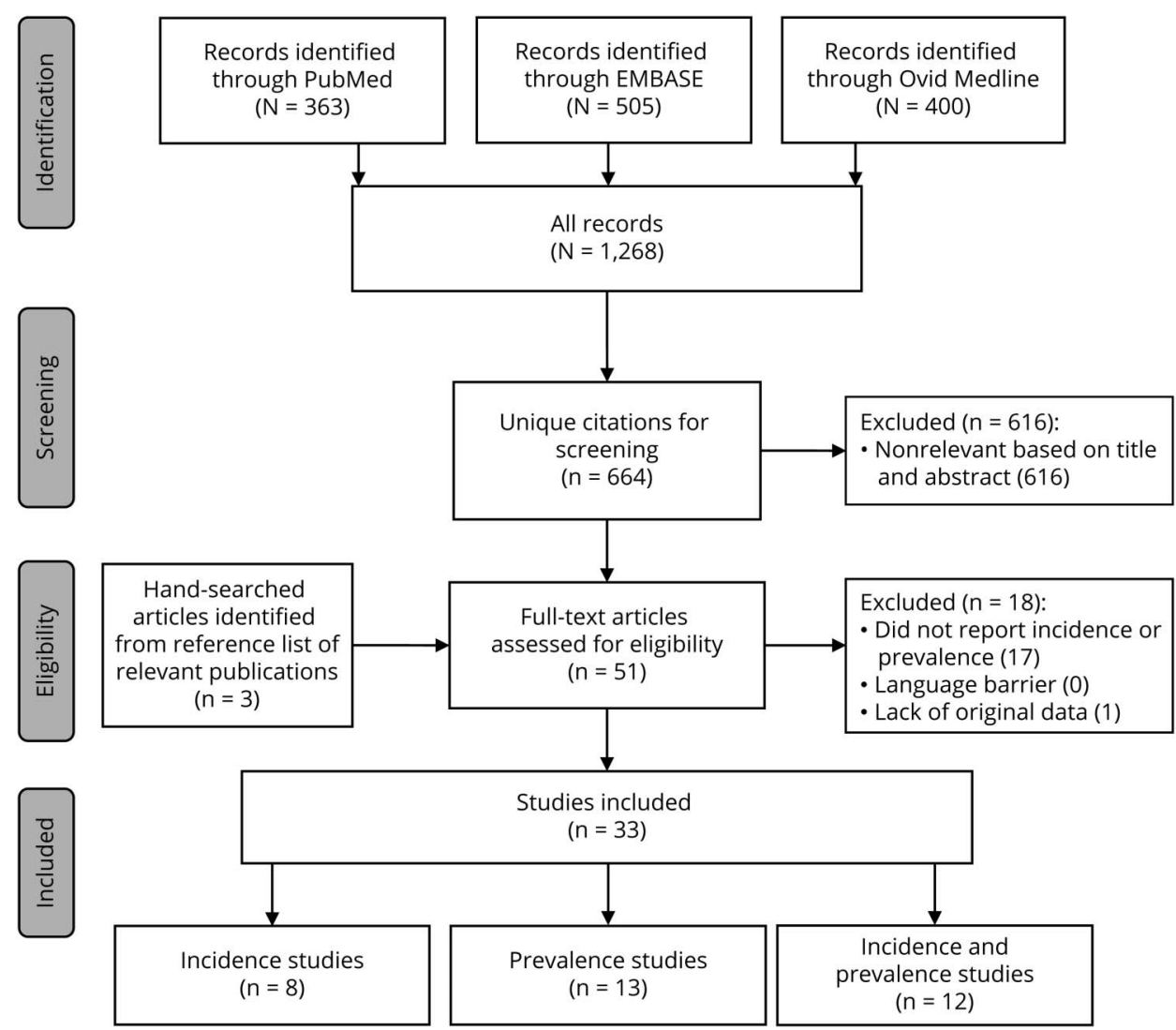

AQP4-Ab test. 7,11,20-22,27-29,32,34-36,41 Many studies used multiple sources for case detection (clinical departments, registries, and/or laboratory databases), ${ }^{10,12-18,24,26,29-32}$ whereas others used data directly from clinical departments, physicians, $^{11,19,21-23,27,28,33-42}$ or laboratory units. ${ }^{20}$ Confidence intervals were not always presented. ${ }^{11,19-21,28,33,42}$ Standardized estimates are essential when comparing findings in populations with different age and sex distributions, but these were rarely provided. One study applied the US standard population, ${ }^{10} 1$ used the Japanese standard population, ${ }^{38}$ and 4 others the WHO standard population. ${ }^{14,16,18,31}$

Some prevalence and incidence estimates were obtained before the discovery of the AQP4-Ab and were solely based on the diagnostic criteria from 1999 restricted to optic neuritis (ON) and transverse myelitis (TM). ${ }^{26,40}$ Two other studies applied the 1999 criteria if the AQP4-Ab test was not available, but the 2006 criteria when the AQP4-Ab test was performed. $^{24,25}$ Eleven studies purely used the 2006 criteria, $^{14,15,19,23,27-29,34,38,39,41} 8$ other studies reported estimates based on the 2006 criteria combined with other AQP4$\mathrm{Ab}$-seropositive (AQP4-Ab+) cases, ${ }^{10-12,16,17,32,33,36}$ and 10 other studies calculated estimates by applying the 2015 IPND criteria. ${ }^{14,15,18,19,21,22,30,31,35,37,38}$ Two studies included only AQP4-Ab+ patients with NMO/NMOSD. ${ }^{13,20}$ Another used the 2015 IPND criteria for unknown or AQP4$\mathrm{Ab}$-seronegative (AQP4-Ab-) NMOSD due to lack of access to AQP4-Ab test. ${ }^{42}$

\section{Incidence}

Considerable variation was observed in the definition of the incident event and the duration of the observation period for incidence. Most studies considered incident cases based on the disease onset, ${ }^{10,13-16,18,19,28,30,31}$ but a few calculated incidence by the diagnosis date, ${ }^{17,27,43}$ date of AQP4-Ab test, ${ }^{20}$ or calculated by using the point prevalence and the average disease duration to prevalence day. ${ }^{26}$ Other studies did not define incident event. $^{21-24,29,41}$ We identified 20 reports regarding the incidence of NMO/NMOSD (tables 1-4, supplementary tables 1 and 2, doi.org/10.5061/dryad.prr4xgxh9). The observation period for the incidence rate ranged from 2 to 27 years. ${ }^{16,19}$ These may lead to remarkable differences in the incidence estimates. Incidence rates were reported between 0.039 and 0.73 / 100,000 person-years for adults ${ }^{10,18}$ and between 0.01 and $0.06 /$ 100,000 person-years for children ${ }^{21,28,29}$ (age $<18$ years).

\section{Geography and Ethnicity: Incidence}

The geographic distribution of the studies is demonstrated in tables 1-4. Most studies were conducted in Europe with predominantly White populations. 
Table 1 Study Design and Completeness of the Epidemiologic Studies Including Adults in Predominantly White Populations

\begin{tabular}{|c|c|c|c|c|c|c|c|c|}
\hline $\begin{array}{l}\text { Country-study area } \\
\text { (year) }\end{array}$ & $\begin{array}{l}\text { No. of cases } \\
\text { cohort/ } \\
\text { prevalent/ } \\
\text { incident }\end{array}$ & Source & Source population & $\begin{array}{l}\text { Incident } \\
\text { cases }\end{array}$ & Criteria & Included as NMO/NMOSD & $\begin{array}{l}\text { AQP4-Ab } \\
\text { test }\end{array}$ & $\begin{array}{l}\text { Validated } \\
\text { patient }\end{array}$ \\
\hline $\begin{array}{l}\text { Austria-nationwide } \\
(2011)^{13}\end{array}$ & $71 / 62 / 17$ & $\begin{array}{l}\text { Neurology departments; all } \\
\text { registered neurologists; laboratory }\end{array}$ & $\begin{array}{l}\text { Reported by clinicians and } \\
\text { laboratory }\end{array}$ & $\begin{array}{l}\text { Disease } \\
\text { onset }\end{array}$ & $\begin{array}{l}\text { Only AQP4- } \\
\text { Ab+ NMO/ } \\
\text { NMOSD }\end{array}$ & Only AQP4-Ab+ NMO/NMOSD & CBA & NS \\
\hline $\begin{array}{l}\text { United Kingdom-South } \\
\text { East Wales (2012) }\end{array}$ & $14 / 14 /-$ & $\begin{array}{l}\text { Registry; laboratory; neurologists; } \\
\text { neurology department }\end{array}$ & $\begin{array}{l}\text { Screened a broad } \\
\text { population }\end{array}$ & - & $\begin{array}{l}\text { 2006, AQP4- } \\
\text { Ab+ ON/LETM }\end{array}$ & NMO, AQP4-Ab+ ON or LETM & NS & Yes \\
\hline $\begin{array}{l}\text { United } \\
\text { Kingdom-Northwest } \\
\text { England }(2013)^{12}\end{array}$ & $13 / 8 / 7$ & $\begin{array}{l}\text { WCNN records; regional hospitals; } \\
\text { laboratory; BNSU }\end{array}$ & $\begin{array}{l}\text { Screened a broad } \\
\text { population }\end{array}$ & NS & $\begin{array}{l}\text { 2006, AQP4- } \\
\text { Ab+ ON/LETM }\end{array}$ & NMO, AQP4-Ab+ ON or LETM & CBA & Yes \\
\hline $\begin{array}{l}\text { Netherlands-nationwide } \\
(2016)^{20}\end{array}$ & $94 /-/ 89$ & Laboratory & Reported by the laboratory & NS & NS & AQP4-Ab+ NMOSD & CBA & No \\
\hline Spain-Catalonia (2018) & $74 / 67 / 47$ & $\begin{array}{l}\text { Neurology departments with MS unit; } \\
\text { NPR (NMO diagnosis); laboratory }\end{array}$ & $\begin{array}{l}\text { Only NMO diagnosis and } \\
\text { AQP4-Ab+ from the } \\
\text { laboratory, reported by } \\
\text { clinicians }\end{array}$ & $\begin{array}{l}\text { Disease } \\
\text { onset }\end{array}$ & 2006,2015 & 2015 & $\begin{array}{l}\text { CBA (96\%), } \\
\text { IHC (3\%), } \\
\text { ELISA (1\%) }\end{array}$ & Yes \\
\hline $\begin{array}{l}\text { Denmark-Southern } \\
\text { Denmark }(2011)^{17}\end{array}$ & 42/NS/NS & $\begin{array}{l}\text { Natalizumab registry; DNPR (ON, TM, } \\
\text { and MS; NMO); regional neurology } \\
\text { and ophthalmology departments }\end{array}$ & $\begin{array}{l}\text { Screened a broad } \\
\text { population }\end{array}$ & $\begin{array}{l}\text { Date of } \\
\text { diagnosis }\end{array}$ & $\begin{array}{l}\text { 2006, AQP4- } \\
\text { Ab+ ON/LETM }\end{array}$ & $\begin{array}{l}\text { NMO, AQP4-Ab+ ON, LETM, } \\
\text { autoimmune diseases } \\
\text { related to NMOSD }\end{array}$ & CBA, IP & Yes \\
\hline $\begin{array}{l}\text { Denmark-Central } \\
\text { Denmark }(2018)^{19}\end{array}$ & $5 /-13$ & $\begin{array}{l}\text { Neurology departments (IDD) data } \\
\text { set }\end{array}$ & $\begin{array}{l}\text { Screened a broad } \\
\text { population }\end{array}$ & $\begin{array}{l}\text { Disease } \\
\text { onset }\end{array}$ & 2006,2015 & 2015 & ELISA, CBA & Yes \\
\hline $\begin{array}{l}\text { Denmark-nationwide } \\
(2018)^{15}\end{array}$ & $56 / 50 / 27$ & $\begin{array}{l}\text { NPR; MS Registry; neurology } \\
\text { departments; laboratories }\end{array}$ & $\begin{array}{l}\text { Screened a broad } \\
\text { population }\end{array}$ & $\begin{array}{l}\text { Disease } \\
\text { onset }\end{array}$ & 2006, 2015 & 2015 & $\begin{array}{l}79.5 \% \text { CBA, } \\
13.7 \% \text { IP, } \\
6.8 \% \text { ELISA }\end{array}$ & Yes \\
\hline $\begin{array}{l}\text { Sweden-nationwide } \\
(2019)^{16}\end{array}$ & $92 / 89 / 82$ & NPR and laboratory & $\begin{array}{l}\text { Only NMO diagnosis and } \\
\text { AQP4-Ab+ from the } \\
\text { laboratory }\end{array}$ & $\begin{array}{l}\text { Disease } \\
\text { onset }\end{array}$ & $\begin{array}{l}\text { 2006, AQP4- } \\
\mathrm{Ab}+\text { ON/LETM }\end{array}$ & NMO, AQP4-Ab+ NMOSD & $\begin{array}{l}\text { Before } \\
2012 \text { IB, } \\
\text { later CBA }\end{array}$ & Yes \\
\hline Hungary (2/3) (2020) $)^{31}$ & $154 / 123 / 101$ & $\begin{array}{l}\text { NPR; neurology departments; } \\
\text { laboratories }\end{array}$ & $\begin{array}{l}\text { Screened a broad } \\
\text { population }\end{array}$ & $\begin{array}{l}\text { Disease } \\
\text { onset }\end{array}$ & 2015 & 2015 & $100 \%$ CBA & Yes \\
\hline $\begin{array}{l}\text { Australia and New } \\
\text { Zealand-nationwide } \\
(2017)^{18}\end{array}$ & $149 / 147 / 27$ & $\begin{array}{l}\text { Adult and pediatric neurology } \\
\text { departments; laboratory }\end{array}$ & $\begin{array}{l}\text { Reported by clinicians and } \\
\text { seropositive from the } \\
\text { laboratory }\end{array}$ & $\begin{array}{l}\text { Disease } \\
\text { onset }\end{array}$ & 2015 & 2015 & $\begin{array}{l}\text { CBA (46\%), } \\
\text { IF-tissue } \\
(100 \%)\end{array}$ & Yes \\
\hline $\begin{array}{l}\text { United States-Olmsted } \\
\text { County }(2016)^{10}\end{array}$ & $6 / 6 / 1$ & $\begin{array}{l}\text { Registries; neurology department; } \\
\text { neurologists (all patients with IDD) }\end{array}$ & $\begin{array}{l}\text { Screened a broad } \\
\text { population }\end{array}$ & $\begin{array}{l}\text { Disease } \\
\text { onset }\end{array}$ & $\begin{array}{l}\text { 2006, AQP4- } \\
A b+\text { NMOSD }\end{array}$ & $\begin{array}{l}\text { NMO; AQP4-Ab+ NMOSD with single } \\
\text { or recurrent TM, single or recurrent } \\
\text { ON, brainstem or cerebral attack }\end{array}$ & CBA & Yes \\
\hline
\end{tabular}

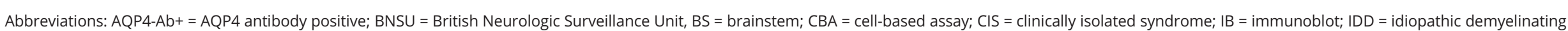

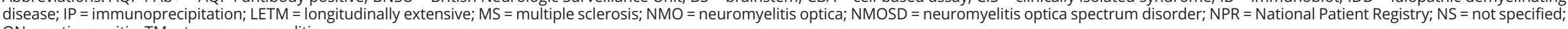
$\mathrm{ON}=$ optic neuritis: $\mathrm{TM}=$ transverse myelitis. 
Table 2 Study Design and Completeness of the Epidemiologic Studies Including Adults in Predominantly Non-White Populations

\begin{tabular}{|c|c|c|c|c|c|c|c|c|}
\hline $\begin{array}{l}\text { Country-study area } \\
\text { (year) }\end{array}$ & $\begin{array}{l}\text { No. of cases } \\
\text { cohort/ } \\
\text { prevalent/ } \\
\text { incident }\end{array}$ & Source & Source population & Incident cases & Criteria & Included as NMO/ NMOSD & $\begin{array}{l}\text { AQP4-Ab } \\
\text { test }\end{array}$ & $\begin{array}{l}\text { Validated } \\
\text { patient }\end{array}$ \\
\hline $\begin{array}{l}\text { Canada-British } \\
\text { Columbia }(2015)^{27}\end{array}$ & $31 /-/ 31$ & Hospital data set & Only NMO & Date of diagnosis & 2006 & NS & NS & No \\
\hline $\begin{array}{l}\text { India-Mangalore } \\
(2014)^{33}\end{array}$ & $11 /-/ 11$ & Different specialists; department & Reported by clinician & - & $\begin{array}{l}\text { 2006, AQP4- } \\
\text { Ab+ ON/ } \\
\text { LETM }\end{array}$ & $\begin{array}{l}\text { ON, ADEM, CIS, TM, spastic } \\
\text { paraplegia, and } \\
\text { myelopathy }\end{array}$ & NS & Yes \\
\hline $\begin{array}{l}\text { Japan-Tokachi } \\
(2012)^{39}\end{array}$ & $3 / 3 /-$ & $\begin{array}{l}\text { Single: } 14 \text { MS- and NMOSD-related } \\
\text { institutions inside and outside this area }\end{array}$ & $\begin{array}{l}\text { Reported by } \\
\text { clinicians }\end{array}$ & - & 2006 & NMO 2006 & CBA & No \\
\hline $\begin{array}{l}\text { Japan-Tokachi } \\
(2017)^{38}\end{array}$ & $14 / 14 /-$ & $\begin{array}{l}\text { Single: } 14 \text { MS- and NMOSD-related } \\
\text { institutions inside and outside this area }\end{array}$ & $\begin{array}{l}\text { Reported by } \\
\text { clinicians }\end{array}$ & - & 2006, 2015 & 2015 & CBA & Yes \\
\hline $\begin{array}{l}\text { Japan-nationwide } \\
(2018)^{11}\end{array}$ & $4,377(1,042)$ & $\begin{array}{l}\text { Departments based on random selection } \\
\text { using a stratified sampling method }\end{array}$ & $\begin{array}{l}\text { Reported by } \\
\text { clinicians }\end{array}$ & - & $\begin{array}{l}\text { 2006, AQP4- } \\
\text { Ab+ NMOSD }\end{array}$ & NMO, AQP4-Ab+ NMOSD & NS & No \\
\hline $\begin{array}{l}\text { Malaysia_Penang } \\
\text { Island (2018) }\end{array}$ & 28/14/- & Hospital databases; private neurologists & $\begin{array}{l}\text { Reported by } \\
\text { clinicians }\end{array}$ & - & 2015 & 2015 & CBA & Yes \\
\hline $\begin{array}{l}\text { Malaysia-nationwide } \\
(2019)^{22}\end{array}$ & $580 / 580 / \mathrm{NS}$ & Hospitals & $\begin{array}{l}\text { Reported by } \\
\text { clinicians }\end{array}$ & NS & 2015 & 2015 & NS & Yes \\
\hline $\begin{array}{l}\text { UAE-Abu Dhabi } \\
(2018)^{21}\end{array}$ & 10/10/8 & Department databases & $\begin{array}{l}\text { Screened a broad } \\
\text { population }\end{array}$ & NS & 2015 & 2015 & NS & Yes \\
\hline Iran-Isfahan (2014) ${ }^{34}$ & 95/95/- & Hospital database & $\begin{array}{l}\text { Only NMO reported } \\
\text { in the database }\end{array}$ & - & 2006 & NS & NS & NS \\
\hline $\begin{array}{l}\text { Iran-Southwest } \\
(2015)^{36}\end{array}$ & $51 / 51 /-$ & $\begin{array}{l}\text { Neurology departments; MS } \\
\text { clinic; neurologists }\end{array}$ & $\begin{array}{l}\text { Screened a broad } \\
\text { population }\end{array}$ & - & $\begin{array}{l}\text { 2006, } \\
\text { NMOSD }\end{array}$ & $\begin{array}{l}\text { NMO/NMOSDs: } \geq 1 \text { : ON; LETM; rec. } \\
\text { BS; rec. hypothalamus attack; rec. } \\
\text { cerebral attack; plus } \geq 1 \text { : AQP4-Ab+; } \\
\text { MRI typical of NMO }\end{array}$ & NS & Yes \\
\hline Iran-Tehran $(2017)^{35}$ & 103/103/- & Department & $\begin{array}{l}\text { Reported by } \\
\text { clinicians }\end{array}$ & - & 2015 & NS & $\begin{array}{l}\text { ELISA } \\
\text { (9 patients } \\
\text { unreported) }\end{array}$ & Yes \\
\hline $\begin{array}{l}\text { Kazakhstan-Semej } \\
\text { town }(2019)^{42}\end{array}$ & 10 & Department & $\begin{array}{l}\text { Reported by } \\
\text { clinicians }\end{array}$ & - & 2015 & $\begin{array}{l}\text { Criteria for the unknown/negative } \\
\text { status of AQP4-Ab }\end{array}$ & Not tested & Yes \\
\hline $\begin{array}{l}\text { Mexico-Mexico City } \\
(2008)^{40}\end{array}$ & $34 / \mathrm{NS} /-$ & Hospital case records & $\begin{array}{l}\text { Suspected MS and } \\
\text { NMO }\end{array}$ & - & 1999 & According to 1999 & Not tested & Yes \\
\hline $\begin{array}{l}\text { Cuba-nationwide } \\
(2009)^{26}\end{array}$ & $58 / 58 / \mathrm{NS}$ & $\begin{array}{l}\text { All neurologic, rehabilitation, pediatric, ophthalmologic department; } \\
\text { neurologists; GP; National Clinical Trial of Interferon-2b in RRMS } \\
\text { (1993-2003); Cuban Record of MS; Cuban MS Society and the National } \\
\text { Association of Persons with MS }\end{array}$ & $\begin{array}{l}\text { Screened a broad } \\
\text { population }\end{array}$ & $\begin{array}{l}\text { Prevalence rates } \\
\text { and the disease } \\
\text { durations to } \\
\text { prevalence day }\end{array}$ & 1999 & $\begin{array}{l}\text { According to } 1999 \text { and spectrum } \\
\text { disorders of NMO: those with rec. } \\
\text { LETM and severe rec. ON }\end{array}$ & Not tested & Yes \\
\hline
\end{tabular}


In smaller, predominantly White cohorts, the incidence of NMO/NMOSD was between 0.07 and 0.4/100,000 personyears. ${ }^{10,12,17,19}$ In larger White studies applying the 2006 criteria, the incidence was between 0.029 and 0.04/100,000 person-years. ${ }^{14,15}$ When including only AQP4-Ab+ NMOSD, the incidence ranged from 0.054 to $0.08 / 100,000$ personyears. ${ }^{13,20} \mathrm{NMO}$ and AQP4-Ab+ NMOSD together gave an incidence of $0.079 / 100,000$ person-years, ${ }^{16}$ whereas based on the last NMOSD 2015 criteria, it ranged from 0.037 to 0.132 / 100,000 person-years. ${ }^{14,15,18,31}$

Only a few incidence estimates are available from other ethnicities: in Caribbean-African 0.22-0.4/100,000 person-years $(1999 / 2006 \text { criteria })^{24}$ and $0.7 / 100,000$ person-years (2006 criteria plus AQP4-Ab+ NMOSD) ${ }^{10}$ in selected Asian populations 0.39-0.6/100,000 person-years (2015 IPND criteria), ${ }^{22,27}$ and in Arab populations 0.17/100,000 personyears (2015 IPND criteria). ${ }^{21}$ The Dutch study described a higher incidence among non-White compared with White populations living in the same geographic area. ${ }^{20}$

Four studies from White ${ }^{14,28-30}(0.01-0.06 / 100,000$ personyears) pediatric populations and 1 from an $\mathrm{Arab}^{21}$ (0.06/100,000 person-years) pediatric population reported incidence estimates of NMO/NMOSD. Three of these were based on a single incident case observed in a period of $7-19$ years (table 4). ${ }^{21,28,29}$

\section{Sex- and Age-Related Incidence}

The sex-specified incidence rates were higher in females than in males, although the difference was less remarkable or disappeared at extremes of age (supplementary tables 1 and 2, doi. org/10.5061/dryad.prr4xgxh9). ${ }^{10,14,15,24,28-31}$ Of interest, in Sweden, over the period 1987-2006, the incidence of NMOSD in males $(0.151 / 100,000$ person-years [95\% CI: 0.085-0.261]) was more than 2 times higher compared with females (0.067) 100,000 person-years [95\% CI: 0.044-0.098]), whereas between 2007 and 2013, the incidence of NMOSD in females (0.150/ $100,000$ person-years [95\% CI: $0.108-0.203]$ ) was more than 2 times greater compared with males $(0.066 / 100,000$ person-years [95\% CI: 0.032-0.123]). ${ }^{16}$ The highest incidence rates in both sexes were found in the $40-59$ year age group. ${ }^{14,31}$ Incidence studies showed that $20 \%-28 \%$ of the incidence cohorts had a late-onset NMOSD (age $\geq 60$ years). ${ }^{14,31}$

The pediatric cohort of Iceland ${ }^{28}$ and Denmark ${ }^{29}$ (age $\leq 18$ years) identified a single male case in each country, whereas the very recent Danish study ${ }^{30}$ (age $\leq 18$ years) found 2 male and 2 female cases. The Catalonia study ${ }^{14}$ reported 3 female and 2 male pediatric patients.

\section{Serostatus and Incidence}

Only 4 publications described the serostatus-specific incidence. ${ }^{10,14,15,31}$ These found a higher incidence of AQP4$\mathrm{Ab}+\mathrm{NMOSD}$ compared with AQP4-Ab- patients. In the United States, the incidence of AQP4-Ab+ NMOSD was $0.07 / 100,000$ person-years (95\% CI: 0.0-0.21) based on a single case, whereas no AQP4-Ab- incident cases were identified. The same study 


\begin{tabular}{|c|c|c|c|c|c|c|c|}
\hline Country & $\begin{array}{l}\text { Population } \\
\text { (million) }\end{array}$ & $\begin{array}{l}\text { Period of } \\
\text { incidence } \\
\text { (Prevalence day) }\end{array}$ & Incidence (CI) & Prevalence $(\mathrm{Cl})$ & $\begin{array}{l}\text { Prevalence according } \\
\text { to ethnicity (CI) }\end{array}$ & $\begin{array}{l}\text { Sex-specific } \\
\text { prevalence }(\mathrm{CI})\end{array}$ & Sex-specific incidence $(\mathrm{Cl})$ \\
\hline Austria $^{13}$ & 8.4 (FP) & $\begin{array}{l}\text { March } \\
2008-D e c e m b e r \\
2011 \text { (Dec 2011) }\end{array}$ & $0.054(0.01-0.31)$ & $0.7(0.17-0.96)$ & ND & ND & ND \\
\hline $\begin{array}{l}\text { United Kingdom-South } \\
\text { East Wales }\end{array}$ & $0.713(F P)$ & (May 1, 2010) & ND & $1.96(1.22-2.97)$ & ND & ND & ND \\
\hline $\begin{array}{l}\text { United } \\
\text { Kingdom-Northwest } \\
\text { England }^{12}\end{array}$ & 1.14 (age >16 y) & $\begin{array}{l}\text { 2003-2010 } \\
\text { (December 30, } \\
\text { 2010) }\end{array}$ & $0.08(0.03-0.16)$ & $0.72(0.31-1.42)$ & $\begin{array}{l}\text { White: } 0.66(0.27-1.37) \text {; } \\
\text { Non-White: } 1.8 \\
(0.05-10.04)\end{array}$ & ND & ND \\
\hline Netherlands ${ }^{20}$ & $16.6(\mathrm{FP})$ & $\begin{array}{l}\text { May 2009-April } \\
2015\end{array}$ & $\begin{array}{l}0.09 \text { (NS); White: } 0.08 \text {; } \\
\text { Non-White: } 0.19\end{array}$ & ND & ND & ND & ND \\
\hline Spain-Catalonia ${ }^{14}$ & $7.52(\mathrm{FP})$ & $\begin{array}{l}\text { 2006-2015 (January } \\
1,2016)\end{array}$ & $\begin{array}{l}\text { 2006: } 0.040(0.026-0.055) \\
\text { 2015: } 0.063(0.045-0.081)\end{array}$ & $\begin{array}{l}\text { 2006: } 0.58(0.57-0.60) \\
\text { 2015: } 0.89(0.87-0.91)\end{array}$ & ND & $\begin{array}{l}\text { F: } 1.31(1.27-0.34) ; \\
\text { M: } 0.46(0.44-0.48)\end{array}$ & $\begin{array}{l}\text { F: } 0.09(0.060-0.121) ; \text { M: } 0.035 \\
(0.016-0.054)\end{array}$ \\
\hline $\begin{array}{l}\text { Denmark-Southern } \\
\text { Denmark }^{17}\end{array}$ & 0.952 (age $\geq 15 y$ ) & $1998-2008$ (NS) & $0.4(0.3-0.54)$ & $4.4(3.1-5.7)$ & ND & ND & ND \\
\hline $\begin{array}{l}\text { Denmark-Central } \\
\text { Denmark }^{19}\end{array}$ & $1.27(\mathrm{FP})$ & $2012-2013$ & $\begin{array}{l}\text { 2006: } 0.08 \text { (NS); 2015: } 0.12 \\
\text { (NS) }\end{array}$ & ND & ND & ND & ND \\
\hline Denmark-nationwide ${ }^{15}$ & 4.6 (age $\geq 16 y$ ) & $\begin{array}{l}\text { 2007-2013 (January } \\
1,2014)\end{array}$ & $\begin{array}{l}\text { 2006: } 0.029(0.014-0.051) ; \\
\text { 2015: } 0.070(0.046-0.102)\end{array}$ & $\begin{array}{l}\text { 2006: } 0.566 \\
(0.370-0.830) ; 2015: \\
1.09(0.81-1.44)\end{array}$ & $\begin{array}{l}\text { White } 1.007(0.732-1.35) \\
\text { Asian: } 2.47(0.674-6.33)\end{array}$ & $\begin{array}{l}\text { F: } 1.76(1.26-2.39) ; \\
\text { M: } 0.40(0.18-0.76)\end{array}$ & $\begin{array}{l}\text { F: } 0.104(0.063-0.16) ; \mathrm{M}: 0.037 \\
(0.015-0.075)\end{array}$ \\
\hline Sweden ${ }^{16}$ & $9.6(\mathrm{FP})$ & $\begin{array}{l}\text { 2007-2013 } \\
\text { (December 31, } \\
\text { 2013) }\end{array}$ & $0.079(0.055-0.103)$ & $1.04(0.85-1.26)$ & ND & ND & Extensive data are reported \\
\hline Hungary $(2 / 3)^{31}$ & 6.4 (age $\geq 16$ y) & $\begin{array}{l}\text { 2006-2015 (January } \\
1,2016)\end{array}$ & $0.132(0.108-0.161)$ & $1.91(1.52-2.28)$ & ND & $\begin{array}{l}\text { F: } 3.22(2.65-3.89) ; \\
\text { M: } 0.47(0.25-0.78)\end{array}$ & F: 0.22 (0.178-0.27); M: $0.04(0.02-0.06)$ \\
\hline $\begin{array}{l}\text { Australia and New } \\
\text { Zealand }^{18}\end{array}$ & $27.67(\mathrm{FP})$ & $\begin{array}{l}\text { 2009-2012 (July } 1, \\
\text { 2013) }\end{array}$ & $0.037(0.036-0.038)$ & $0.7(0.66-0.74)$ & $\begin{array}{l}\text { Asian: } 1.57(1.15-1.98) ; \\
\text { Other: } 0.57(0.50-0.65)\end{array}$ & ND & ND \\
\hline $\begin{array}{l}\text { United States-Olmsted } \\
\text { County }^{10}\end{array}$ & $0.146(\mathrm{FP})$ & $\begin{array}{l}\text { 2003-2011 } \\
\text { (December 31, } \\
\text { 2011) }\end{array}$ & $0.07(0.00-0.21)^{\mathrm{a}}$ & $3.9(0.8-7.1)^{a}$ & $\begin{array}{l}\text { White (5): } 4.0(0.5-7.5) \\
\text { Black (1): } 13.0(0.0-38.4)\end{array}$ & $\begin{array}{l}\text { F: } 6.5(0.8-12.1) \\
\text { M: } 1.4(0.0-4.1)\end{array}$ & F: 0.14 (0.0-0.43); M: 0 \\
\hline $\begin{array}{l}\text { Canada-British } \\
\text { Columbia }\end{array}$ & Only Asian: 0.54 & $1986-2010$ & 0.39 to 0.6 & ND & - & $\begin{array}{l}\text { Extensive data are } \\
\text { reported }\end{array}$ & ND \\
\hline India-Mangalore ${ }^{33}$ & 0.419 (FP) & (2013) & ND & $2.6(\mathrm{NS})$ & ND & ND & ND \\
\hline Japan-Tokachi ${ }^{39}$ & $0.352(\mathrm{FP})$ & (March 31, 2011) & ND & $0.9(0.2-2.5)$ & ND & ND & ND \\
\hline
\end{tabular}


Table 3 The Incidence and Prevalence of NMO/NMOSD in Epidemiology Studies (Incidence:/100,000 Person-Years, Prevalence:/100,000 Persons) (continued)

\begin{tabular}{|c|c|c|c|c|c|c|c|}
\hline Country & $\begin{array}{l}\text { Population } \\
\text { (million) }\end{array}$ & $\begin{array}{l}\text { Period of } \\
\text { incidence } \\
\text { (Prevalence day) }\end{array}$ & Incidence $(\mathrm{Cl})$ & Prevalence $(\mathrm{CI})$ & $\begin{array}{l}\text { Prevalence according } \\
\text { to ethnicity (CI) }\end{array}$ & $\begin{array}{l}\text { Sex-specific } \\
\text { prevalence }(\mathrm{CI})\end{array}$ & Sex-specific incidence (CI) \\
\hline Japan-Tokachi ${ }^{38}$ & $0.344(\mathrm{FP})$ & (March 31, 2016) & ND & $\begin{array}{l}\text { 2006: } 2.1 \text { (NS); 2015: } 4.1 \\
(2.2-6.9)\end{array}$ & ND & ND & ND \\
\hline Japan-nationwide ${ }^{11}$ & $130(\mathrm{FP})$ & $(2011)$ & ND & $\begin{array}{l}\text { NMO: } 1.64 \text { (NS); NMO/ } \\
\text { NMOSD: } 3.42 \text { (NS) }\end{array}$ & ND & ND & ND \\
\hline $\begin{array}{l}\text { Malaysia-Penang } \\
\text { Island }^{37}\end{array}$ & $0.702(\mathrm{FP})$ & (July 1, 2017) & ND & $1.99(1.09-3.35)$ & $\begin{array}{l}\text { Chinese: } 3.31(1.76-5.67) ; \\
\text { Malays: } 0.43(0.01-2.38)\end{array}$ & ND & ND \\
\hline Malaysia-nationwide ${ }^{22}$ & 28.7 (age >12 y) & $\begin{array}{l}\text { 2013-2017 } \\
\text { (December 29, } \\
\text { 2017) }\end{array}$ & $0.39(0.35-0.47)$ & $1.94(1.77-2.10)$ & $\begin{array}{l}\text { Wrong denominators } \\
\text { were applied! }\end{array}$ & ND & ND \\
\hline UAE-Abu Dhabi ${ }^{21}$ & $\begin{array}{l}2.9 \text { (FP); UAE: } 0.55 \\
\text { adult UAE (>20): } \\
0.26\end{array}$ & 2010-2016 (NS) & $\begin{array}{l}\text { FP: } 0.05 \text { (NS); UAE } \\
\text { adult (>20): } 0.17 \text { (NS) }\end{array}$ & FP: 0.34 (NS) & UAE adult (>20): 1.76 (NS) & ND & ND \\
\hline Iran-Isfahan ${ }^{34}$ & NS & (October 10, 2013) & ND & $1.9(1.6-2.3)$ & ND & $\begin{array}{l}\mathrm{F}: 2.7(2-3.3) ; \mathrm{M}: 1.2 \\
(0.8-1.6)\end{array}$ & ND \\
\hline Iran-Southwest Iran 36 & $4.5(\mathrm{FP})$ & (November 2013) & ND & $1.1(1.04-1.16)$ & ND & $\begin{array}{l}\text { F: } 2.00(1.92-2.09) ; \\
\text { M: } 0.26(0.23-0.29)\end{array}$ & ND \\
\hline Iran-Tehran ${ }^{35}$ & 11.9 (FP) & (NS) & ND & $0.86(0.76-0.91)$ & ND & $\begin{array}{l}\text { F: } 1.35 \text { (NS); M: } 0.26 \\
\text { (NS) }\end{array}$ & ND \\
\hline $\begin{array}{l}\text { Kazakhstan-Semej } \\
\text { town }{ }^{42}\end{array}$ & 0.35 & (NS) & ND & 4.9 (NS) & ND & ND & ND \\
\hline Mexico-Mexico City ${ }^{40}$ & $18.4(\mathrm{FP})$ & (NS) & ND & $1.3(0.9-1.8)$ & ND & ND & ND \\
\hline Cuba ${ }^{26}$ & 11.18 (FP) & $\begin{array}{l}\text { 2003-2004 } \\
\text { (November 30, } \\
\text { 2004) }\end{array}$ & $0.053(0.040-0.068)$ & $0.52(0.39-0.67)$ & $\begin{array}{l}\text { White: } 0.43(0.29-0.61) \text {; } \\
\text { Non-White: } 0.69 \\
(0.46-1.01)\end{array}$ & $\begin{array}{l}\text { F: } 0.91(0.68-1.20) ; \\
\text { M: } 0.12(0.05-0.25)\end{array}$ & ND \\
\hline $\begin{array}{l}\text { France-Martinique and } \\
\text { Guadeloupe } \\
24,25\end{array}$ & 0.705 (FP) & $\begin{array}{l}\text { 1992-2007 June 30, } \\
\text { 2007) }\end{array}$ & $0.19(0.15-0.23)$ & $4.2(3.7-5.7)$ & ND & F: $7.14(4.45-9.83)$ & $\begin{array}{l}\text { F: } 1992-97: 0.42(0.11-0.73) ; 1997-2002: \\
0.28(0.03-0.53) ; 2002-07: 0.32(0.06-0.58)\end{array}$ \\
\hline France-Martinique ${ }^{10}$ & $0.392(\mathrm{FP})$ & $\begin{array}{l}\text { 2003-2011 } \\
\text { (December 31, } \\
\text { 2011) }\end{array}$ & $0.73(0.45-1.01)^{a}$ & $10(6.8-13.2)^{\mathrm{a}}$ & $\begin{array}{l}\text { White: } 6.1(0.0-18.1) \\
\text { Black: } 11.5(7.8-15.2)\end{array}$ & $\begin{array}{l}\text { F: } 17.4(11.6-23.3) ; \\
\text { M: } 2.5(0.0-4.9)\end{array}$ & F: 1.31 (0.79-1.83); M: $0.12(0.00-0.30)$ \\
\hline Costa Rica ${ }^{23}$ & 3.88 (age >13 y) & $\begin{array}{l}\text { August } \\
2011 \text {-December } \\
2015\end{array}$ & $0.13-0.44(N S)$ & ND & ND & ND & ND \\
\hline
\end{tabular}

Abbreviations: $\mathrm{F}=$ Female; $\mathrm{FP}$ = full population; $\mathrm{M}=$ male; $\mathrm{NS}=$ not specified; $\mathrm{ND}=$ not done; $\mathrm{UAE}=$ The United Arab Emirates.

a Only age-standardized estimates were reported. 
determined the estimates in Martinique and showed a 5 times higher incidence of AQP4-Ab+NMOSD (0.65/100,000 personyears [95\% CI: 0.39-0.92]) in comparison with AQP4-AbNMOSD. ${ }^{10}$ In Catalonia, AQP4-Ab+ incidence increased from $0.015 / 100,000$ person-years (95\% CI: -0.002 to 0.004 ) in the pediatric population to $0.062 / 100,000$ person-years (95\% CI: $0.028-0.096)$ in adults, whereas the incidence of AQP4-AbNMOSD was low in all age groups (ranging from 0.006 to 0.029 / 100,000 person-years) but similar to seropositive incidence in children. ${ }^{14}$ In Denmark, the incidence of AQP4-Ab+ patients was 2-fold higher compared with AQP4-Ab-NMOSD, ${ }^{15}$ whereas the Hungarian study revealed 5-fold greater incidence estimates of the AQP4-Ab+ NMOSD. ${ }^{31}$

\section{Temporal Changes in Incidence}

Some studies reported the annualized incident rate over longer time periods, where temporal changes could be evaluated (supplementary table 1, doi.org/10.5061/dryad. prr4xgxh9). Studies from the French West Indies covering time periods 1992-1997, 1997-2002, and 2002-2007 and from British Columbia covering the period 1986-2010 showed stable incidence. $^{25,27}$ Studies with shorter observational periods published from the Netherlands (6 years), ${ }^{20}$ Abu Dhabi ( 7 years), ${ }^{21}$ Denmark ( 7 years; not published data), ${ }^{15}$ Catalonia (10 years), ${ }^{14}$ and Hungary (10 years; not published data $)^{31}$ revealed no temporal changes in the annualized incidence rates. In contrast to this, the Swedish study found an increasing incidence in females from 0.07/100,000 person-years (95\% CI: 0.04-0.09) between 1987 and 2006 to 0.15/100,000 person-years (95\% CI: 0.11-0.20) between 2007 and 2013. ${ }^{16}$ In Costa Rica, an increase from 0.13 to 0.44 was reported between 2011 and 2015 . $^{23}$

\section{Prevalence}

We recognized 25 articles presenting prevalence estimates ranging from 0.34 to $10 / 100,000$ in adults and from 0.06 to $0.22 / 100,000$ in children (tables $1-3$, supplementary tables 1 and 2, doi.org/10.5061/dryad.prr4xgxh9). The number of prevalent cases ranged from 6 to 4,377 in adults ${ }^{10,11}$ and from 3 to 11 in children. ${ }^{14,41}$ The census date for prevalence was not reported in 7 publications. ${ }^{11,17,21,33,35,40,42}$

\section{Geography and Ethnicity: Prevalence}

The geographic distribution of prevalent studies is presented in tables 1-4. In smaller studies with predominantly White populations, the prevalence varied from 0.72 to 4.4 to/100,000, including patients with NMO based on the 2006 criteria and AQP4-Ab-positive NMOSD. ${ }^{10,12,17,32}$ In larger populations, it spanned from 0.57 to $0.58 / 100,000$ based on the 2006 criteria $^{14,15}$; 1.04/100,000 counting NMO and AQP4-Ab+ cases $^{16}$; 0.7/100,000 involving only AQP4-Ab+ patients ${ }^{13}$; and from 0.7 to 1.91 using the 2015 IPND criteria. ${ }^{14,15,18,31,34-36}$

Seven reports from predominantly Asian populations revealed a prevalence between 1.57 and 4.9/100,000. ${ }^{22,33,37-39,41,42}$ Similar to incidence data, the highest prevalence was found in African populations: $10 / 100,000^{10}$ and $4.2 / 100,000^{24}$ before the era of AQP4-Ab detection. The prevalence estimate of a single study from Arab countries demonstrated a prevalence of $1.76 / 100,000$ in adults. ${ }^{21}$

A few studies provided head-to-head comparison of the prevalence of NMOSD in different ethnicities living in the same geographic area under similar environmental White ancestry. $10,12,15,18,22,26,37$ They found that Asian and African ancestries have a higher risk to develop NMO/NMOSD than White ancestry. ${ }^{10,12,15,18}$ Furthermore, within Asian ethnicities, a higher prevalence was found among Chinese compared with Malays. ${ }^{37}$ When recalculating the prevalence rates of the nationwide Malaysian study based on their presented row data, similar difference can be seen between Chinese and Malay ethnicities. ${ }^{22}$

\section{Sex- and Age-Related Prevalence}

All studies that calculated the sex-specific estimates found the highest prevalence among females, which was 2.3-7.6times greater than for males, both in Whites and Africans (table 3). ${ }^{10,14,15,26,31,34-36}$ Prevalence curves by age had a peak from 30 to 39 in India and between 40 and 59 years for both sexes in Catalonia and Hungary. ${ }^{14,31}$ For females in Australia and New Zealand, ${ }^{18}$ in Tehran and Cuba, ${ }^{26,35}$ the peak prevalence age was between 40 and 49 years and between 45 and 55 years in the French Indies (supplementary table 1, doi.org/10.5061/dryad.prr4xgxh9). ${ }^{24}$

Data are scarce in pediatric populations (table 4). The only 2 studies providing sex-specific prevalence in children reported 1.5 to 2 times higher prevalence for females. ${ }^{14,35}$

\section{Serostatus and Prevalence}

The prevalence of AQP4-Ab+ NMOSD was greater in the 5 studies reporting serostatus-specific data and indicated a seropositive to seronegative ratio of 2.3:1 in Denmark, ${ }^{15} 3.4: 1$ in Japan, ${ }^{38}$ 3.8:1 in Martinique, ${ }^{10} 5: 1$ in the United States, ${ }^{10}$ and 5.2:1 in Hungary. ${ }^{31}$ However, this ratio depends also on applied criteria and definition of AQP4-Ab- cases. The serostatusspecific prevalence by age showed higher frequency of AQP4$\mathrm{Ab}-\mathrm{NMOSD}$ in children. ${ }^{14}$

\section{Temporal Changes in Prevalence}

Two studies from Japan evaluated the same geographic area of Tokachi province over approximately 5-year intervals and showed an increasing prevalence, but different methodological approaches and NMO/NMOSD criteria may also account for this change. ${ }^{38,39}$ In 2011, the research group primarily aimed to evaluate MS epidemiology, but also identified patients with NMO using 2006 criteria and calculated NMO prevalence showing $0.9 / 100,000$ (95\% CI: $0.2-2.5){ }^{39}$ In contrast, the surveillance in 2016 was dedicated to NMO/NMOSD and used both 2006 and 2015 criteria: a considerably higher prevalence was found (2006 criteria: 2.1/100,000; 2015 IPND criteria: 4.1/100,000 [95\% CI: 2.2-6.9] $).^{38}$ An increased prevalence was observed in the French Indies from 1.88/ 100,000 (95\% CI: $0.82-2.94$ ) in 1992 to $4.20 / 100,000$ (95\% CI: 2.70-5.70) in 2007, but this was explained by a decrease in mortality. ${ }^{24}$ To date, no study evaluated at the population level over a long period of time mortality in NMOSD. 
Table 4 Studies Reporting on the Epidemiology of NMO/NMOSD in Pediatric Populations

\begin{tabular}{|c|c|c|c|c|c|c|c|}
\hline Country & Japan $^{41}$ & Iceland $^{28}$ & Denmark $^{29}$ & Denmark $^{30}$ & Spain $^{14}$ & $\operatorname{Iran}^{35}$ & $\begin{array}{l}\text { The United Arab } \\
\text { Emirates }^{21}\end{array}$ \\
\hline Published (year) & 2016 & 2015 & 2018 & 2019 & 2018 & 2017 & 2018 \\
\hline Study area & Nationwide & Nationwide & Nationwide & Nationwide & Catalonia & Tehran & Abu Dhabi \\
\hline Population (million) & 17.5 & NS & 1.8 & 1.8 & NS & 3.02 & NS \\
\hline Age group (y) & $\leq 15$ & $\leq 18$ & $<18$ & $<18$ & $0-17$ & $0-19$ & $<20$ \\
\hline $\begin{array}{l}\text { NMOSD cases/ } \\
\text { prevalent/incident }\end{array}$ & $14 / 11 /-$ & $1 /-/ 1$ & $1 /-/ 1$ & $4 /-/ 4$ & $\mathrm{NS} / 3 / 5$ & NS/5/- & NS/-/1 \\
\hline Source & $\begin{array}{l}\text { Pediatric departments of } \\
\text { hospitals } \\
\text { (randomly selected hospitals } \\
\text { according to stratification) }\end{array}$ & Hospital & $\begin{array}{l}\text { NPR, MS, and } \\
\text { hospital }\end{array}$ & $\begin{array}{l}\text { Register, laboratory, and } \\
\text { hospital }\end{array}$ & $\begin{array}{l}\text { Members of organizations, neurology } \\
\text { department with MS unit, national patient } \\
\text { registry (NMO diagnosis), and laboratory }\end{array}$ & $\begin{array}{l}\text { Reported by } \\
\text { clinician }\end{array}$ & Department \\
\hline Source population & Screened a bigger population & $\begin{array}{l}\text { Screened a } \\
\text { bigger } \\
\text { population }\end{array}$ & $\begin{array}{l}\text { Screened a bigger } \\
\text { population }\end{array}$ & Screened a bigger population & $\begin{array}{l}\text { Only NMO diagnosis and seropositive } \\
\text { cases from the laboratory or } \\
\text { reported by clinicians }\end{array}$ & NS & $\begin{array}{l}\text { Screened a bigger } \\
\text { population }\end{array}$ \\
\hline $\begin{array}{l}\text { Definition of } \\
\text { incident cases }\end{array}$ & - & Disease onset & Disease onset & Disease onset & Disease onset & - & NS \\
\hline Criteria & 2006 & 2006 & 2006 & 2015 & 2015 & 2015 & 2015 \\
\hline $\begin{array}{l}\text { Included as NMO/ } \\
\text { NMOSD }\end{array}$ & According to 2006 & $\begin{array}{l}\text { According to } \\
2006\end{array}$ & According to 2006 & According to 2015 & According to 2015 & NS & According to 2015 \\
\hline AQP4-Ab test & NS & NS & NS & CBA/ELISA & CBA & $\begin{array}{l}\text { ELISA (not all } \\
\text { tested) }\end{array}$ & NS \\
\hline Incidence/100,000 & ND & 0.06 (NS) & $0.01(0.015-0.074)$ & $0.031(0.011-0.082)$ & $0.037(0.005-0.070)$ & ND & $\operatorname{UAE}(<19): 0.06$ (NS) \\
\hline $\begin{array}{l}\text { Period of incidence } \\
\text { rate }\end{array}$ & - & $1990-2009$ & $2008-2015$ & $2008-2018$ & $2006-2016$ & - & $2010-2016$ \\
\hline Prevalence/100,000 & $0.06(0.04-0.08)$ & ND & ND & ND & $0.22(0.19-0.24)$ & $0.16(\mathrm{NS})$ & ND \\
\hline Prevalence day & December 31, 2007 & - & - & - & 2016 & NS & - \\
\hline $\begin{array}{l}\text { Prevalence } \\
\text { according to } \\
\text { ethnicity }\end{array}$ & NS & - & - & - & NS & NS & - \\
\hline Age at onset (mean) & 10.3 & $15-17 y$ & 13.3 & 11.4 & NS & NS & NS \\
\hline Female & $80 \%$ & $0 \%$ & $0 \%$ & NS & prev: $66 \%$, inc: $60 \%$ & $60 \%$ & $100 \%$ \\
\hline AQP4-Ab positive & NS & NS & NS & $75 \%$ & prev: $33 \%$, inc: $40 \%$ & NS & $0 \%$ \\
\hline $\begin{array}{l}\text { Annual incidence } \\
\text { rate/100,000 }\end{array}$ & - & NS & NS & NS & NS & - & NS \\
\hline
\end{tabular}




\section{Demographic Data}

The basic demographic data are summarized in table 4 and supplementary table 2, doi.org/10.5061/dryad.prr4xgxh9. The mean age at onset varied from $29.2^{36}$ to 45.7 years, ${ }^{13}$ whereas the median was between $30.5^{21}$ and $43^{11,26}$ years. The youngest age at onset was reported from Iran (mean age: 29.2-31.54 years). ${ }^{34-36}$ The percentage of females in different epidemiologic cohorts ranged from $55 \%$ to $100 \% .^{33,37,39}$ However, highest percentages of females ranging from $86 \%$ to $100 \%$ have been consistently found in populations from West Indies and Far East. ${ }^{11,24,26,37-39,44}$ The percentage of AQP4-Ab seropositivity was between $27 \%$ and $100 \%$ (excluding studies only on AQP4-Ab+ cases and where AQP4-Ab was not tested). ${ }^{33,37,39}$ The lowest percentage of AQP4$\mathrm{Ab}$ seropositivity was reported in India, ${ }^{33}$ followed by the 3 Iranian studies, ${ }^{34-36}$ and the study from Southern Denmark. ${ }^{17}$

The mean follow-up was between 5.85 and 9.9 years, ${ }^{26,40}$ and the median from 3.5 to 12.5 years. ${ }^{10,32}$ The duration of followup was not mentioned in 11 publications. 12,13,17-21,23,24,27,37,39

The majority of the patients had recurrent disease (71\%-97.5\%); only 1 study in Iran described monophasic disease in $60 \%$ of the cases, but they did not provide data about serostatus of these patients. ${ }^{34}$ Progressive disease course was reported in 2 studies and was found between $0.2 \%$ and $0.6 \%{ }^{22,31}$ The frequency of patients with NMO/NMOSD, who did not survive until the census day, ranged between $0 \%$ and $38.5 \%$ when reported. ${ }^{10,12}$

\section{Discussion}

This systematic review provides several observations: (1) $\mathrm{NMO} / \mathrm{NMOSD}$ is a rare disease; $(2)$ is reported worldwide in a variety of ethnic ancestry populations; (3) studies investigating the incidence and prevalence of NMOSD are diverse; (4) the number of well-designed epidemiologic studies of NMOSD is increasing; (5) there is a female and $\mathrm{AQP} 4-\mathrm{Ab}+$ predominance; (6) incidence and prevalence estimates show a peak age in middle-aged adults; however, these are often distorted by incomplete capture (possibly premature death) of older cohorts, and (7) late-onset NMOSD (age $\geq 60$ years) is responsible for one-fourth of the incidence cases. (8) Most of the results suggest that African ethnicity is associated with the highest incidence and prevalence, and White ethnicity may have the lowest. It seems that there has been no definite change in the incidence of $\mathrm{NMO} /$ NMOSD over time. Rare head-to-head comparative studies suggest a role of genetic factors in developing NMOSD. However, there is need for more well-designed (large source population with long observation period) studies to identify potentially concealed features of NMOSD epidemiology.

One factor that can contribute to the noticed variation could be the genetic mixture of the observed populations. This is supported by studies involving different ethnic groups living in the same geographic region, where environmental factors are considered comparable. ${ }^{10,12,15,18,20,37,45}$ Epidemiologic 
Table 5 Reported Limitations and Observed Considerations of the Epidemiologic Studies of NMO/NMOSD in Predominantly White Populations

Country Limitations reported by the authors

Further potential limitation

Austria $^{13}$ Only seropositive severe case).

United Kingdom-South Not reported.

East Wales $^{32}$

\section{United}

Kingdom-Northwest

Kingdom-
England $^{12}$

\begin{tabular}{ll}
\hline Netherlands $^{20}$ & "Mild cases and rare phenotypes could have been missed. Have not had clinical and imaging \\
data of all included patients."
\end{tabular}

Spain-Catalonia $^{14}$

“CHSS registries started in 2011 the inclusion of primary care and specialized outpatients visits, and only those patients coded as NMO and Devic disease were revised....could not rule out underrepresentation of cases prior to 2005 when AQP4-IgG testing was available and a selection bias toward more recently active cases. Not all IDD were reevaluated."

Denmark-Southern

Denmark $^{17,43}$

"Lower number of MS from the departments than expected. Misclassification of cases the on the diagnosis of NMOSD and not based on the disease onset."

Denmark $^{19}$

"There was insufficient information in medical records or incomplete diagnostic assessment in 50 cases. 36 cases of these patients had not been tested previously via their local departments. Two-year time span was relatively short."

Denmark-nationwide ${ }^{15}$ "Did not review patients with area postrema syndrome, encephalitis, or unspecified demyelinating CNS disease. Patients in whom a severe first relapse led to death may have been lost if AQP4 measurement was not conducted at the onset. Different AQP4 test methods might influence our results."

Sweden ${ }^{16} \quad$ "Retrospective design. The dependency on clinicians' diagnosis or suspicion of NMO/NMOSD. Did not have access to records from outpatient care that was not hospital-based. Some milder cases of NMOSD may have been missed."

Hungary $(2 / 3)^{31}$

"We may have missed cases with severe onset, who died before the AQP4-antibody test could have been performed. We did not screen for all types of demyelinating disorder. Due to missing crucial data, we excluded 86 patients with a single episode of ON or TM, but none were reported as possible NMOSD. Missing cases with pediatric onset may slightly decrease."

Australia and New Zealand $^{18}$

"Only a proportion of our suspected cases had testing for AQP4 antibodies with a cell-based assay. We have not tested every patient with demyelinating disease of the CNS for AQP4 antibodies. These limitations are, however, only likely to have a relatively small impact on the overall prevalence. Only currently or recently active cases who have been seen in clinics or undergone AQP4 antibody testing will have been identified."

United States-OImsted "Serum was not obtained from all potential cases. Underrepresentation of patients with area postrema and brainstem symptoms."

County database, treatment influence, timing of the MRI." Asgari et al. 2019.: "Incidence rate was based

Denmark-Central

No further comment.

Short follow-up. Small population size.

No further comment.

It was restricted to AQP4-Ab+ cases. Only a single source. Cls were not calculated. Prevalence was not calculated. Clinical and imaging data: not for all patients-no case validation.

Narrow Cls

Missing data were not described (17\%); questionnaire was applied (recall bias). Different AQP4IgG assays and $38 \%$ of seronegative cases.

Cls were not reported.

No further comment.

Validated only on patients registered with NMO in the national patient registry (ICD-10:36.0 or ICD-9: 9.34A) and patients with known AQP4 antibody seropositivity from a central laboratory-potential misclassification bias. The number of patients before the available AQP4 antibody test could be underestimated. Serostatus was not published. CBA available only since 2012.

No further comment.

Short period for incidence estimate.

Very small sample size (2 patients died between the census date and subsequent follow-up). 
studies and large case series have reached the same conclusion that individuals from Asian ${ }^{15,18,33,37-39}$ and African ${ }^{10,12,46}$ ancestries have a disproportionately greater risk to develop NMOSD compared with White ethnic groups. This suggests that genetic factors may be important in disease susceptibility. This hypothesis is also supported by familial clustering recognized in approximately $3 \%$ of the cases ${ }^{47}$ and by the results of a whole-genome association study. ${ }^{6}$ Of interest, genetic susceptibility alleles for NMOSD were more closely linked to those of systemic lupus erythematosus than MS. ${ }^{6}$

Besides these population-based studies, several research groups explored the frequency of NMOSD among patients with idiopathic inflammatory diseases. These works found increased susceptibility for NMOSD in populations with Asian, African, Arab, and Latin American background paralleled with a lower frequency of MS. ${ }^{48-51}$

As an environmental trigger factor, latitudinal gradient was considered in a survey across Australia and New Zealand, where a slightly higher prevalence of NMOSD was noted at lower latitudes. ${ }^{18}$ The nationwide Japanese survey also found a greater prevalence of NMO/NMOSD in the Southern part of Japan. ${ }^{11} \mathrm{~A}$ review found no correlation between latitude and prevalence; however, the compared prevalences were calculated based on different diagnostic criteria, i.e., both NMO and NMOSD. ${ }^{52}$ The comparison of large population-based studies in Europe involving White populations in neighboring countries in Northern and Central Europe (Denmark, Sweden, Austria, and Hungary) suggests that genetic factors may be responsible for some of these latitudinal differences. $13,15,16,31$

Different results among the studies could also reflect variations in the study design; the size of the study population; the timing and length of the study; the applied diagnostic criteria; access to health care and antibody tests; the type of antibody assays used; whether the estimates were age standardized; the underlying population's structure (age and sex); and ethnic mixture. These factors may remarkably limit the generalizability and reliability of the results. Estimates can be affected by multiple biases and random errors, which could even mask the potential differences among the geographic areas, ethnicities, and environmental factors.

The variable performance of $\mathrm{AQP} 4-\mathrm{Ab}$ assays could lead to misdiagnosis of patients due to false-positive or false-negative results. ${ }^{53,54} \mathrm{CBA}$ uses transfected live or fixed cells and either semiquantitative immunofluorescence microscopy or fluorescence-activated cell sorting to detect AQP4-Ab. By using a semiquantitative method, the results are dependent on the experience of the person assessing the staining pattern. Further methods such as ELISA, tissue-based immunofluorescence, and immunoprecipitation have particularly shown a tendency to false-positive detection. ${ }^{55,56}$

The recent studies from Catalonia, Sweden, Denmark, Australia/ New Zealand, and Hungary showed similarities in study design: 
Table 6 Reported Limitations and Observed Considerations of the Epidemiologic Studies of NMO/NMOSD in Predominantly Non-White Populations

Country Limitations reported by the authors

\section{Further potential limitation}

India-Mangalore ${ }^{33} \quad$ "Registry method may have led to underdetection of the cases."

Unknown how many were tested for AQP4-Ab; definition of NMOSD is unsure. Small sample size. 95\% Cls were not provided. Access to health care in India can differ remarkably from Europe.

Japan-Tokachi ${ }^{39} \quad$ Not focused on NMO. Single source. Small sample size. Only prevalence was investigated.

Japan-Tokachi ${ }^{38} \quad$ Not reported. Survey-based study where they have not searched for overlooked cases.

Japan-nationwide ${ }^{11} \quad$ Not reported.

Estimates were derived with a statistical method. No case reviews. Cls, demographic/clinical data not provided.

\section{Malaysia-Penang Island ${ }^{37} \quad$ Not reported.}

Single source. Small sample size. Only prevalence was investigated.

Malaysia-nationwide 22 "Hospital referral bias. The small sample size and the lack of disease awareness/participation by patients and physicians. The registry-based method of capturing hospital data resulting in underestimated figures and the role of traditional taboos/beliefs and faith healers."

The authors stated that the size of the population was $28.7 \mathrm{~m}$ and citizens by the ethnic groups were the following: $68.8 \%$ Malay (NMOSD cases: 275 -prevalence: 0.98 ), 23.4\% Chinese (NMOSD cases: 271 - prevalence: 0.96 ) and $7 \%$ Indian (NMOSD cases: 24-prevalence: 0.08 ), and $1 \%$ others. The size of the Chinese population should be 6.72 million (23.4\% of 28.7 million) counting with the 271 identified NMOSD cases results in a prevalence of about $4.04 / 100,000$. For the Malay ethnic group of 19.75 million ( $68.8 \%$ of 18.7 million-275 NMOSD cases), the prevalence of NMOSD is $1.39 / 100,000$. When the authors report on the prevalence according to ethnicity, they applied wrongly the whole population $(28.7 \mathrm{~m})$ as denominator instead of the population's number of each ethnic groups. The capture-recapture method was applied, which requests some conditions such as independent sources, but in this study, the same sources were used to capture and to recapture cases.

The United Arab

Emirates-Abu Dhabi ${ }^{21}$

"Small sample size. The method of retrospective chart review limited data gathering. 44\% of patients in the database were not tested for AQP4-IgG. Many patients did not have a complete work-up for possible seronegative NMOSD. Emirati nationals may also receive their care internationally therefore data may have been missing."

\begin{tabular}{ll}
\hline Iran-Isfahan $^{34}$ & Not reported. \\
\hline Iran-Southwest $^{\mathbf{3 6}}$ & $\begin{array}{l}\text { "No exact population number for ethnicity was available. Some patients may have been } \\
\text { referred to larger city for treatment, so they did not have the exact number of patients." }\end{array}$
\end{tabular}

Iran-Tehran $^{35}$ "The prevalence of NMOSD might be underestimated because some of the NMOSD cases might not refer to the center studied."

Canada-British

Columbia $^{27}$

Not reported.

Mexico-Mexico City ${ }^{40}$

No AQP4 antibody test. Clinical based (not population based). Risk for input bias.

Cuba $^{26}$

Fance-Martinique and Not reported.

Guadeloupe ${ }^{25}$
Not reported

Single source. Clswere not given. Sex-and age-standardized rateswould be interesting because only $1 / 3$ of the population is female, and the majority of the population is under 20 years.

No detailed description of the study design (inclusion, AQP4 antibody test). No detailed results.

Used a special interpretation of NMOSD. Only 35 patients were tested for AQP4-Ab. No control for double counting. Population structure is different from Europe (younger). Their oldest NMO/ NMOSD patients were 58 years old at the disease onset. Therefore, age-standardized estimates would be helpful. Short follow-up.

Recall bias may have occurred. Potential selection bias due to single-source approach. ELISA AQP4 antibody test may be false positive and false negative (9 results were not reported).

Unknown AQP4-Ab test. NMO incidence for 1986 cannot be complete, only incidence calculation.

Cases with only ON or TM (confusing how the monophasic disease was interpreted because all patients with monophasic type with initial event of TM had also impaired vision. So they were either not monophasic or the initial event was NMO).

Old criteria before AQP4-Ab test. Incidence was calculated based on prevalence and disease duration.

Old criteria before AQP4-Ab test. Small sample size. 
large White populations, multiple sources, large proportion tested with CBA, and access to free health care. The results from Catalonia, Denmark, Sweden, and Australia/New Zealand showed similar incidence (0.039-0.063/100,000 person-years) and prevalence $(0.7-1.09 / 100,000)$, but the Danish nationwide study only investigated the adult population with regard to prevalence. ${ }^{15}$ The Hungarian crude and age-standardized prevalence and incidence were higher than the Catalonian, Danish, Australian/New Zealand, and Swedish estimates both according to the 2015 NMOSD and 2006 NMO criteria. ${ }^{14,18}$ The 2006 criteria for NMO are more strict because they do not allow NMO diagnosis with a single ON or LETM attack despite the presence of AQP4-Ab. Therefore, it is unlikely that the difference observed between the Hungarian and the other 4 studies would be caused by a difference in the threshold of AQP4-Ab assays. In addition, the population-based Hungarian and Danish studies were designed by overlapping research groups and used similar designs. The major laboratory for the Hungarian study participated in an international validation of $\mathrm{CBA}^{53}$

There have been 4 studies conducted in Scandinavian adults, including 2 nationwide studies ${ }^{15,16}$ and 2 smaller regional Danish studies. ${ }^{17,19}$ The results of 3 of the 4 reports seem to be consistent with each other and with other large White population studies, but are contrary to the data published from the small study in Southern Denmark delineating the highest prevalence $(4.4 / 100,000)$ and incidence (4.0/ $1,000,000$ person-year) so far in preponderantly White ancestry. ${ }^{17}$ According to the estimates from the Southern Denmark, the nationwide Danish study should have recognized 202 prevalent Danish NMOSD cases, but only 50 prevalent cases were identified. It is unlikely that such an inconsistency would be caused by different study methods. More likely, the higher rates may be due to less strict adherence to criteria or alternative diagnoses in $\mathrm{AQP} 4-\mathrm{Ab}$ - patients and patients with low and transient AQP4-Ab seropositivity. ${ }^{15}$ The final estimates of the nationwide Danish study were similar to the nationwide study in Sweden ${ }^{16}$ and to another regional study in Denmark. ${ }^{19}$

The Swedish study showed that the incidence was higher in males in the period of 1987-2006. Because of the low number of NMO cases during that time and the overlapping confidence intervals, these estimates should be interpreted with caution. Overall, $74 \%$ of all diagnosed patients with $\mathrm{NMO}$ in Sweden were women. ${ }^{16}$

Another smaller study of White ethnicity ${ }^{10}$ in Olmsted County also revealed a higher prevalence than the larger studies. However, the incidence estimate was comparable with those of the larger studies. The comprehensive approach of the study from Olmsted County is a strong advantage, such as each individual with suspected demyelinating disease in the county's population was tested for AQP4 antibody with CBA providing a probably higher recognition rate of cases. However, this study investigated a small population of 145,979 residents, and there were only 6 prevalent cases (prevalence: 3.9/100,000 (95\% CI: $0.8-7.1)$ ) and a single incident case between 2003 and 
2011 (incidence: 0.07/100,000 person-years (95\% CI: $0.00-0.21)){ }^{10}$ They also reported that 2 prevalent patients died in the following year after the census date, which would have reduced the prevalence rate to $2.7 / 100,000$, assuming that there were no additional new cases in the following year. Furthermore, because of the small population and few NMOSD cases, even missing or adding 1 or 2 cases might have a considerable impact on the estimates; the lower precision of the estimates is indicated by the broad confidence intervals. Considering these, interpreting the differences between the large studies and the Olmsted County study is difficult.

The recent Dutch study solely estimated the incidence of AQP4$\mathrm{Ab}+\mathrm{NMOSD}$ to be 0.09 presumably based on the 2015 IPND $\mathrm{AQP} 4-\mathrm{Ab}+$ criteria, but confidence intervals are not reported, and clinical and radiologic information were available only in $38 \%$ of the incident cases. ${ }^{20}$ The ethnicity of the cases may have influenced the results, as the incidence was $0.08 / 100,000$ for Whites and $0.19 / 100,000$ for non-Whites. It is not clear whether disease onset was defined by the onset of the clinical symptoms or the date of the positive AQP4-Ab. Altogether, the incidence of the Dutch AQP4-Ab+ White NMOSD population seems to be more similar to other White population reports. ${ }^{12-16,19}$

Two works from the United Kingdom used a combination of 2006 criteria $^{3}$ and the 2007 NMOSD definition. ${ }^{4}$ These publications described the epidemiology of NMO/NMOSD in a small area of Wales and England. ${ }^{12,32}$ In Wales, a prevalence of 1.96/ 100,000 (95\% CI: 1.22-2.97) was observed derived from a background population of 712,572 inhabitants. ${ }^{32}$ Surprisingly, $21 \%$ of the reported prevalent cases were under age 20 years, resulting in a higher prevalence in the age group from 0 to 19 years than in the age group from 20 to 49 years. No other epidemiologic study has shown similar findings. This may be an anomaly of the relatively small study population or some hidden capture bias. Opposite to this, the prevalence of NMO/NMOSD was 0.72/ 100,000 (95\% CI: 0.31-1.42) among the 1.14 million adult residents of England, and the incidence was 0.08/100,000 (95\% CI: 0.03-0.16) similar to the other large White population studies.

Three separate investigations were published from different regions of Iran. ${ }^{34-36}$ The demographic and clinical data were different from other studies around the world, especially in Isfahan. ${ }^{38}$ All 3 Iranian studies found a lower percentage of AQP4-Ab-positive cases (46.8\%-66.3\%), lower mean age at onset (29.2-31.5 years), and lower last Expanded Disability Status Scale score compared with most of the other studies. This inconsistency may be due to different ethnicities or population structure, but limitations should be also considered (tables 5 and 6).

The first recent study from an Arab region, Abu Dhabi, showed a greater prevalence and incidence of NMOSD compared with larger White populations. ${ }^{21}$ The authors provided subgroup analysis for Arab residents and the adult population, but no sex-adjusted and sex- and age-standardized calculations. These would have given more informative estimates, as the percentage of women was only 30\% among the residents, and half of the Emirati citizens in Abu Dhabi were younger than 19 years. ${ }^{21}$

According to the latest studies conducted in Asian populations (Japanese, ${ }^{11,38}$ Indian, ${ }^{33}$ Malaysian-Chinese, ${ }^{22,27,37}$ and Kazakhstan ${ }^{42}$ ), the prevalence ranged from 2.6 to $4.9 /$ 100,000 , and the incidence was between 0.39 and $0.6 /$ 100,000 person-years, which are remarkably higher than in Whites. However, only 2 studies computed the incidence in Asian ancestries. ${ }^{22,27}$ The results from India and Kazakhstan may be an underestimation of the true prevalence due to differently organized health care systems and limited or no access to AQP4-Ab assays. ${ }^{33}$ It should be noted that there is a lack of prevalence and incidence data from continental China.

APQ4-Ab was found in a high proportion of the patients with NMOSD with a few exceptions from India and Iran, ${ }^{33,35,36}$ where low sensitivity assays or other autoantibodies may be suspected. Whereas AQP4-Ab+ patients are likely to be a more consistent cohort to cross compare, $\mathrm{AQP} 4-\mathrm{Ab}$ - cohorts will vary depending on criteria used, access to supportive investigations, and even on the clinician's subjective evaluation. ${ }^{57}$ In addition, antibody against myelin oligodendrocyte glycoprotein (MOG) has been recognized in the AQP4-Ab- NMOSD subgroup. Since the increasing knowledge about MOG-Ab and related diseases, there has been increasing concern to separate MOG-Abpositive patients with NMOSD phenotype from the $\mathrm{AQP} 4-\mathrm{Ab}+$ and double-seronegative NMOSD. ${ }^{58}$ Only epidemiologic studies from Catalonia and Japan had the possibility to test all included AQP4-Ab- patients for anti-MOG. ${ }^{14,38}$ They showed that $0 \%(0 / 3)$ of the AQP4-Ab- prevalent NMOSD cases in the Asian population ${ }^{38}$ vs $47 \%(9 / 19)^{14}$ in the White population were positive for MOG-Ab. More studies are needed to confirm such population differences, especially in cases with low or borderline/uncertain AQP4-Ab positivity. Less standardized methods for MOG-Ab may also contribute to differences.

Epidemiologic studies were conducted in Martinique and Guadeloupe before the era of the AQP4-Ab test and again in Martinique a few years ago. ${ }^{10,24,25}$ Both population-based evaluations presented a high prevalence and incidence in African ancestry regardless of diagnostic criteria. The results without AQP4-Ab measurement were 4.2/100,000 (95\% CI: 3.7-5.7) for crude prevalence and $0.19 / 100,000$ person-years (95\% CI: 0.15-0.23) for crude incidence, whereas the recent study including $\mathrm{AQP} 4-\mathrm{Ab}$-positive patients based on the 2006 criteria gave a prevalence of $10 / 100,000$ (95\% CI: 6.8-13.2) and incidence of $0.73 / 100,000$ person-years (95\% CI: $0.45-1.01)$.

Further epidemiologic studies from Cuba, Mexico, and French West Indies showed lower estimates, which can be expected since the 1999 criteria were applied and access to 
AQP4-Ab testing was not available. ${ }^{26,40,59}$ Overall, studies reported relatively stable annualized incidence without any trend for significant changes over 10-25 years. ${ }^{14,15,20,24,27}$ Only 2 studies showed increasing incidence, ${ }^{16,23}$ whereas a single study showed an increasing prevalence over time that could be explained by reduced mortality. ${ }^{24}$ The increasing awareness of the disease and easier access to AQP4-Ab CBA may explain the rise of incidence. ${ }^{16}$ This together with the earlier introduction of adequate treatments and promising new therapies may result in longer survival and slight increase in the prevalence of NMOSD.

Data regarding pediatric populations are sparse, but indicate that NMOSD rarely develops in childhood. ${ }^{14,21,28-30,35,41}$ In Australia/New Zealand, onset before age 20 years was seen in $12 \%$ (Prof. Simon Broadley, MD, PhD, written personal communication, December 12, 2019).

In common with other systemic autoimmune diseases, studies universally demonstrated a female predominance. This may relate to female sex hormones and hormonal changes. Female genetic susceptibility to autoimmune disorders due to silenced $\mathrm{X}$ chromosome via epigenetic mechanisms has also been suggested. ${ }^{60-62}$ A recent multicenter study found potential association between exogenous hormonal exposure and NMOSD onset, whereas it was not associated with endogenous hormonal exposure. ${ }^{44}$ The average and/or median age at disease onset were similar in the majority of the studies, but all 3 studies from $\operatorname{Iran}^{34-36}$ and the studies from the Caribbeans ${ }^{10,24-26}$ reported a younger age at onset, which could be caused by environmental factors, ethnic influence, or study design. Finally, highest incidence rates reported in West Indians could be due to accumulation of genes of susceptibility coming from White, Indian, and African ancestry in this population.

\section{Limitation}

The major limitation of this work is that we did not use inclusion criteria for study design and quality. Therefore, the included studies have variable study designs that may affect the quality of their results and influence our conclusions. However, we critically reviewed all studies as shown in tables 5 and 6 and report the limitations and point out crucial weaknesses in each publication.

\section{Conclusion}

The incidence and prevalence of NMOSD vary among the studies; this could be due to the effects of genetic and environmental factors, but may also be related to differences in study design, study population, and quality of data. NMOSD has been described worldwide, but it seems to be less frequent in White populations compared with Asian and African ones.

Future studies should be carefully planned to obtain reliable results considering the rarity of the disease and to address epidemiology in more specifically designed settings: (1) by systematic methods of ascertainment with AQP4-Ab testing in all suspected demyelinating disease cases in a given population as gold standard or targeting of high-risk cases as secondary standard; (2) use of CBA for AQP4-Ab testing as recommended; (3) strict adherence to clinical and paraclinical criteria for $\mathrm{AQP} 4-\mathrm{Ab}$ - cases, as epidemiology data within specific serologic groups may be useful in identifying genetic effects and etiologic factors; (4) exclusion of MOG-Abpositive cases; (5) if (1) is not possible, multiple sources and capture/recapture methodology should be used to minimize risks of missed cases; (6) prolonged period of case ascertainment should be considered to avoid missing inactive disease; and (7) inclusion of pediatric sources of cases.

\section{Study Funding}

V. Papp and Z. Illes are supported by Scleroseforeningen (R561-A39086), Odense University Hospital (72-A3846), Forskningspulje mellem RH og OUH (R58-A2888-B347), and Ministry of Human Capacities Hungary (FIKP 2. theme 20765/3/ 2018/FEKUTSTRAT). O. Aktas has received support by the German Ministry for Education and Research (BMBF) for the Neuromyelitis Optica Study Group (NEMOS) as part of the "German Competence Network Multiple Sclerosis" (KKNMS; FKZ 01GI1602B). S.A. Broadley is supported by GINOP 2.3.2-152016-00050 PEPSYS, Multiple Sclerosis Research Australia (11-038). J.-i. Kira is supported by grants from JSPS KAKENHI (Grant No. 16H02657), Health and Labour Sciences Research Grants on Intractable Diseases (H29-Nanchitou (Nan)-Ippan043), and grants from the Japan Agency for Medical Research and Development (AMED) under Grant Numbers JP17ek0109115 and JP18ek0109376. M. Sepulveda and A. Saiz are supported in part by Red Española de Esclerosis Múltiple (REEM) (RD16/ 0015/0002) integrated in the Plan Estatal I+D+I and cofunded by ISCIII-Subdirección General de Evaluación and Fondo Europeo de Desarrollo Regional (FEDER, “Otra manera de hacer Europa”).

\section{Disclosure}

V. Papp has received honoraria for lecturing from Alexion and support for congress participation from Merck. M. Magyari has served on scientific advisory boards for Biogen, Sanofi, Teva, Roche, Novartis, and Merck and has received honoraria for lecturing from Biogen, Merck, Novartis, Sanofi, and Genzyme and support for congress participation from Biogen, Genzyme, Teva, and Roche. O. Aktas has received fees from Almirall, Bayer HealthCare, Biogen, MedImmune, Merck, Roche, Sanofi Genzyme, and Teva for speaker services and advisory boards and research grants from Biogen, Merck, and Sanofi Genzyme. T. Berger has participated in the last 2 years in meetings sponsored by and received honoraria (lectures, advisory boards, and consultations) from pharmaceutical companies marketing treatments for multiple sclerosis: Almirall, Biogen, Biologix, Bionorica, Celgene, MedDay, Merck, Novartis, Roche, Sanofi Aventis/ Genzyme, TG Therapeutics, and Teva. His institution has received financial support in the last 2 years by unrestricted research grants (Biogen, Novartis, Sanofi Aventis/Genzyme, Roche, and Teva) and for participation in clinical trials in multiple sclerosis sponsored by Alexion, Bayer, Biogen, Merck, Novartis, Roche, Sanofi Aventis/Genzyme, and Teva. S.A. Broadley has been a 
principal investigator for clinical trials sponsored by Biogen Idec, Sanofi Genzyme, and Alexion and has received honoraria for lecturing and participation in advisory boards from Bayer Schering, Biogen Idec, Merck, Novartis, Roche, and Sanofi Genzyme. S.A. Broadley has received sponsorship to attend international scientific meetings from Bayer Schering, Biogen Idec, Merck, Novartis, Roche, and Sanofi Genzyme and has been a recipient of unencumbered grants from Biogen Idec and Merck. P. Cabre received support from Novartis for congress participation. A. Jacob has no relevant disclosures. The United Kingdom NMO service is funded by a highly specialized commissioning of the NHS. J.-i. Kira received consultant fees, speaking fees, and/or honoraria from Novartis Pharma, Mitsubishi Tanabe Pharma, Boehringer Ingelheim, Teijin Pharma, Takeda Pharmaceutical Company, Otsuka Pharmaceutical, Astellas Pharma, Pfizer Japan, and Eisai. M.I. Leite is partly supported by NHS England highly specialized commissioning group for a neuromyelitis service. She has received support for scientific meetings and honorariums for presentations from Biogen Idec and Novartis, and for advisory work from Viela Bio. R. Marignier served on the scientific advisory board of MedImmune and received travel funding and speaker honoraria from Biogen, Genzyme, Novartis, Merck Serono, Roche, Sanofi Aventis, and Teva. K. Miyamoto received consultant fees, speaking fees, and/or honoraria from Biogen Japan, Novartis Pharma, Mitsubishi Tanabe Pharma, Asahi Kasei Medical, Alexion Pharma, Sumitomo Dainippon Pharma, and Ono Pharma. J. Palace is partly funded by highly specialized services to run a national congenital myasthenia service and a neuromyelitis service. She has received support for scientific meetings and honorariums for advisory work from Merck Serono, Biogen Idec, Novartis, Teva, Chugai Pharma, Bayer Schering, Alexion, Roche, Genzyme, MedImmune, Euroimmun, MedDay, Abide ARGENX, UCB, and Viela Bio and grants from Merck Serono, Novartis, Biogen Idec, Teva, Abide, MedImmune, Bayer Schering, Genzyme, Chugai, and Alexion. She has received grants from the MS society, Guthy-Jackson Foundation, NIHR, Oxford Health Services Research Committee, EDEN, MRC, GMSI, John Fell, and Myaware for research studies. A. Saiz received compensation for consulting services and speaker honoraria from Bayer Schering, Merck Serono, Biogen Idec, Sanofi Aventis, Teva, Roche, and Novartis. M. Sepulveda received speaking honoraria from Sanofi, Novartis, and Biogen. O. Sveinsson has received grants from GSK and Biogen and personal fees from Biogen and UCB, all outside the submitted work. Z. Illes has served on scientific advisory boards for Biogen, Sanofi, Teva, Roche, Novartis, and Merck and has received honoraria for lecturing from Biogen, Merck, Novartis and Sanofi and for clinical endpoint committees in clinical trials of NMOSD and support for congress participation from Biogen, Genzyme, Merck, Teva, and Roche. Go to Neurology.org/N for full disclosures.

\section{Publication History}

Received by Neurology January 6, 2020. Accepted in final form September 30, 2020.

\section{Appendix Authors}

\begin{tabular}{|c|c|c|}
\hline Name & Location & Contribution \\
\hline $\begin{array}{l}\text { Viktoria } \\
\text { Papp, MD, } \\
\text { PhD }\end{array}$ & $\begin{array}{l}\text { Odense University Hospital, } \\
\text { Denmark }\end{array}$ & $\begin{array}{l}\text { Designed and } \\
\text { conceptualized the study; } \\
\text { acquisition and } \\
\text { interpretation of data; and } \\
\text { drafted the manuscript for } \\
\text { intellectual content }\end{array}$ \\
\hline
\end{tabular}

\begin{tabular}{lll}
\hline $\begin{array}{l}\text { Melinda } \\
\text { Magyari, } \\
\text { MD, PhD }\end{array}$ & $\begin{array}{l}\text { Copenhagen University } \\
\text { Hospital, Rigshospitalet, } \\
\text { Denmark }\end{array}$ & $\begin{array}{l}\text { Study concept and design } \\
\text { and revised the manuscript } \\
\text { for intellectual content }\end{array}$ \\
\hline $\begin{array}{l}\text { Orhan } \\
\text { Aktas, MD }\end{array}$ & $\begin{array}{l}\text { Heinrich-Heine University, } \\
\text { Düsseldorf, Germany }\end{array}$ & $\begin{array}{l}\text { Acquisition of data; } \\
\text { analyzed the data; and } \\
\text { revised the manuscript for } \\
\text { intellectual content }\end{array}$ \\
\hline
\end{tabular}

\begin{tabular}{lll}
\hline Thomas & Medical University of & $\begin{array}{l}\text { Providing updates to data; } \\
\text { interpretation of data; and } \\
\text { Verger, MD } \\
\text { Vienna, Austria } \\
\text { intellectual content }\end{array}$ \\
\hline
\end{tabular}

Simon A Griffith University, Gold r Providing updates to data;

Simon A. Griffith University, Gold Providing updates to data; Broadley, Coast, Gold Coast University interpretation of data; and MD, PhD Hospital, Australia revised the manuscript for intellectual content

\begin{tabular}{lll}
\hline $\begin{array}{l}\text { Philippe } \\
\text { Cabre, MD }\end{array}$ & $\begin{array}{l}\text { Fort-de-France University } \\
\text { Hospital Center, Pierre Zobda } \\
\text { Quitman Hospital, Fort-de- } \\
\text { France, Martinique, France }\end{array}$ & $\begin{array}{l}\text { Interpretation of data and } \\
\text { revised the manuscript for } \\
\text { intellectual content }\end{array}$ \\
$\begin{array}{l}\text { Anu Jacob, } \\
\text { MD }\end{array}$ & $\begin{array}{l}\text { Cleveland Clinic Abu Dhabi, } \\
\text { United Arab Emirates, The } \\
\text { Walton Centre, Liverpool, UK }\end{array}$ & $\begin{array}{l}\text { Interpretation of data and } \\
\text { revised the manuscript for } \\
\text { intellectual content }\end{array}$ \\
\hline
\end{tabular}

\begin{tabular}{lll}
\hline Jun-ichi & Kyushu University, Fukuoka, & Interpretation of data and \\
Kira, MD, & Japan & revised the manuscript for
\end{tabular}
$\begin{array}{ll}\text { PhD } & \text { intellectual content }\end{array}$

\begin{tabular}{lll}
\hline $\begin{array}{l}\text { M. Isabel } \\
\text { Leite, MD, John Radcliffe Hospital, }\end{array}$ & $\begin{array}{l}\text { Interpretation of data and } \\
\text { University of Oxford, UK } \\
\text { DPhil }\end{array}$ & $\begin{array}{l}\text { intellectual content } \\
\text { intel for }\end{array}$ \\
\hline
\end{tabular}

\begin{tabular}{lll}
\hline Romain & Hôpital Neurologique Pierre & Analyzed the data and \\
Marignier, & Wertheimer, Hospices Civils & $\begin{array}{l}\text { revised the manuscript for } \\
\text { MD, PhD }\end{array}$ \\
de Lyon, Bron, France & intellectual content
\end{tabular}

Katsuichi Kindai University Graduate Providing updates to data;

Katsuichi Kindai University Graduate Providing updates to data; $\begin{array}{lll}\begin{array}{l}\text { Miyamoto, } \\ \text { MD, PhD }\end{array} & \text { Japan }\end{array}$ MD, PhD Japan revised the manuscript for intellectual content

\begin{tabular}{lll}
\hline Jacqueline & John Radcliffe Hospital, & $\begin{array}{l}\text { Interpretation of data and } \\
\text { Palace, MD }\end{array}$ \\
& University of Oxford, UK & $\begin{array}{l}\text { revised the manuscript for } \\
\text { intellectual content }\end{array}$
\end{tabular}

\begin{tabular}{lll}
\hline $\begin{array}{l}\text { Albert Saiz, } \\
\text { MD, PhD }\end{array}$ & $\begin{array}{l}\text { Hospital Clínic, Barcelona, } \\
\text { Spain }\end{array}$ & $\begin{array}{l}\text { Interpretation of data and } \\
\text { revised the manuscript for } \\
\text { intellectual content }\end{array}$ \\
\hline
\end{tabular}

\begin{tabular}{lll}
\hline $\begin{array}{l}\text { Maria } \\
\text { Sepulveda, } \\
\text { MD }\end{array}$ & $\begin{array}{l}\text { Hospital Clínic, Barcelona, } \\
\text { Spain }\end{array}$ & $\begin{array}{l}\text { Interpretation of data and } \\
\text { revised the manuscript for } \\
\text { intellectual content }\end{array}$ \\
\hline $\begin{array}{l}\text { Olafur } \\
\text { Sveinsson, } \\
\text { MD, PhD }\end{array}$ & $\begin{array}{l}\text { Karolinska University } \\
\text { Hospital, Karolinska } \\
\text { Institutet, Stockholm, } \\
\text { Sweden }\end{array}$ & $\begin{array}{l}\text { Interpretation of data and } \\
\text { revised the manuscript for } \\
\text { intellectual content }\end{array}$ \\
\hline Zsolt Illes, & Odense University Hospital, \\
MD, PhD & Denmark & $\begin{array}{l}\text { Designed and } \\
\text { conceptualized the study; } \\
\text { acquisition and } \\
\text { interpretation of data; and } \\
\text { revised the manuscript for } \\
\text { intellectual content }\end{array}$ \\
\hline
\end{tabular}




\section{References}

1. Wingerchuk DM, Banwell B, Bennett JL, et al. International consensus diagnostic criteria for neuromyelitis optica spectrum disorders. Neurology 2015;85: 177-189.

2. Lennon VA, Kryzer TJ, Pittock SJ, et al. IgG marker of optic-spinal multiple sclerosis binds to the aquaporin-4 water channel. J Exp Med 2005;202:473-477.

3. Wingerchuk DM, Lennon VA, Pittock SJ, et al. Revised diagnostic criteria for neuromyelitis optica. Neurology 2006;66:1485-1489.

4. Wingerchuk DM, Lennon VA, Lucchinetti CF, et al. The spectrum of neuromyelitis optica. Lancet Neurol 2007;6:805-815.

5. Borisow N, Kleiter I, Gahlen A, et al. Influence of female sex and fertile age on neuromyelitis optica spectrum disorders. Mult Scler 2017;23:1092-1103.

6. Estrada $\mathrm{K}$, Whelan CW, Zhao F, et al. A whole-genome sequence study identifies genetic risk factors for neuromyelitis optica. Nat Commun 2018;9:1929.

7. Pandit L, Asgari N, Apiwattanakul M, et al. Demographic and clinical features of neuromyelitis optica: a review. Mult Scler 2015;21:845-853.

8. Wingerchuk DM, Hogancamp WF, O'Brien PC, et al. The clinical course of neuromyelitis optica (Devic's syndrome). Neurology 1999;53:1107.

9. Miller D, Weinshenker B, Filippi M, et al. Differential diagnosis of suspected multiple sclerosis: a consensus approach. Mult Scler 2008;14:1157-1174.

10. Flanagan EP, Cabre P, Weinshenker BG, et al. Epidemiology of aquaporin-4 autoimmunity and neuromyelitis optica spectrum. Ann Neurol 2016;79:775-783.

11. Miyamoto K, Fujihara K, Kira J, et al. Nationwide epidemiological study of neuromyelitis optica in Japan. J Neurol Neurosurg Psychiatry 2018;89:667-668.

12. Jacob A, Panicker J, Lythgoe D, et al. The epidemiology of neuromyelitis optica amongst adults in the Merseyside county of United Kingdom. J Neurol 2013;260:2134-2137.

13. Aboul-Enein F, Seifert-Held T, Mader S, et al. Neuromyelitis optica in Austria in 2011 to bridge the gap between neuroepidemiological research and practice in a study population of 8.4 million people. PLoS One 2013;8:e79649.

14. Sepúlveda M, Aldea M, Escudero D, et al. Epidemiology of NMOSD in Catalonia: influence of the new 2015 criteria in incidence and prevalence estimates. Mult Scler 2018;24:1843-1851.

15. Papp V, Illes Z, Magyari M, et al. Nationwide prevalence and incidence study of neuromyelitis optica spectrum disorder in Denmark. Neurology 2018;91: e2265-e2275.

16. Jonsson DI, Sveinsson O, Hakim R, et al. Epidemiology of NMOSD in Sweden from 1987 to 2013. Neurology 2019;93:e181-e189.

17. Asgari N, Lillevang ST, Skejoe HPB, et al. A population-based study of neuromyelitis optica in Caucasians. Neurology 2011;76:1589-1595.

18. Bukhari W, Prain KM, Waters P, et al. Incidence and prevalence of NMOSD in Australia and New Zealand. J Neurol Neurosurg Psychiatry 2017;88:632-638.

19. Dale GH, Svendsen KB, Gjelstrup MC, et al. Incidence of neuromyelitis optica spectrum disorder in the Central Denmark Region. Acta Neurol Scand 2018;137: $582-588$.

20. Daniëlle van Pelt E, Wong YYM, Ketelslegers IA, et al. Incidence of AQP4-IgG seropositive neuromyelitis optica spectrum disorders in The Netherlands: about one in a million. Mult Scler J Exp Transl Clin 2016;2:2055217315625652.

21. Holroyd KB, Aziz F, Szolics M, et al. Prevalence and characteristics of transverse myelitis and neuromyelitis optica spectrum disorders in the United Arab Emirates: a multicenter, retrospective study. Clin Exp Neuroimmunol 2018;9:155-161.

22. Viswanathan S, Wah LM. A nationwide epidemiological study on the prevalence of multiple sclerosis and neuromyelitis optica spectrum disorder with important multiethnic differences in Malaysia. Mult Scler 2019;25:1452-1461.

23. Vásquez Céspedes J. Epidemiología de la neuromielitis óptica en Costa Rica: un análisis multicéntrico. Neurol Argentina 2018;10:185-193.

24. Cabre P, Gonzalez-Quevedo A, Lannuzel A, et al. Épidémiologie descriptive de la neuromyélite optique dans le bassin caraibéen. Rev Neurol (Paris) 2009;165:676-683.

25. Cabre P. Environmental changes and epidemiology of multiple sclerosis in the French West Indies. J Neurol Sci 2009;286:58-61.

26. Cabrera-Gómez Ja, Kurtzke JF, González-Quevedo A, et al. An epidemiological study of neuromyelitis optica in Cuba. J Neurol 2009;256:35-44.

27. Lee JD, Guimond C, Yee IM, et al. Incidence of multiple sclerosis and related disorders in Asian populations of British Columbia. Can J Neurol Sci 2015;42:235-241.

28. Gudbjornsson BT, Haraldsson A, Einarsdóttir H, et al. Nationwide incidence of acquired central nervous system demyelination in Icelandic children. Pediatr Neurol 2015;53:503-507.

29. Boesen MS, Magyari M, Koch-Henriksen N, et al. Pediatric-onset multiple sclerosis and other acquired demyelinating syndromes of the central nervous system in Denmark during 1977-2015: a nationwide population-based incidence study. Mult Scler 2018;24:1077-1086.

30. Boesen MS, Jensen PEH, Born AP, et al. Incidence of pediatric neuromyelitis optica spectrum disorder and myelin oligodendrocyte glycoprotein antibody-associated disease in Denmark 2008-2018: a nationwide, population-based cohort study. Mult Scler Relat Disord 2019;33:162-167.

31. Papp V, Iljicsov A, Rajda C, et al. A population-based epidemiological study of neuromyelitis optica spectrum disorder in Hungary. Eur J Neurol 2020;27:308-317.
32. Cossburn M, Tackley G, Baker K, et al. The prevalence of neuromyelitis optica in South East Wales. Eur J Neurol 2012;19:655-659.

33. Pandit L, Kundapur R. Prevalence and patterns of demyelinating central nervous system disorders in urban Mangalore, South India. Mult Scler 2014;20:1651-1653.

34. Etemadifar M, Dashti M, Vosoughi R, et al. An epidemiological study of neuromyelitis optica in Isfahan. Mult Scler 2014;20:1920-1922.

35. Eskandarieh S, Nedjat S, Azimi AR, et al. Neuromyelitis optica spectrum disorders in Iran. Mult Scler Relat Disord 2017;18:209-212.

36. Kashipazha D, Mohammadianinejad SE, Majdinasab N, et al. A descriptive study of prevalence, clinical features and other findings of neuromyelitis optica and neuromyelitis optica spectrum disorder in Khuzestan Province, Iran. Iran J Neurol 2015;14: 204-210.

37. Hor JY, Lim TT, Chia YK, et al. Prevalence of neuromyelitis optica spectrum disorder in the multi-ethnic Penang Island, Malaysia, and a review of worldwide prevalence. Mult Scler Relat Disord 2018;19:20-24.

38. Houzen H, Kondo K, Niino M, et al. Prevalence and clinical features of neuromyelitis optica spectrum disorders in northern Japan. Neurology 2017;89:1995-2001.

39. Houzen $\mathrm{H}$, Niino $\mathrm{M}$, Hirotani $\mathrm{M}$, et al. Increased prevalence, incidence, and female predominance of multiple sclerosis in northern Japan. J Neurol Sci 2012;323: 117-122.

40. Rivera JF, Kurtzke JF, Booth VJA, et al. Characteristics of Devic's disease (neuromyelitis optica) in Mexico. J Neurol 2008;255:710-715.

41. Yamaguchi $Y$, Torisu H, Kira R, et al. A nationwide survey of pediatric acquired demyelinating syndromes in Japan. Neurology 2016;87:2006-2015.

42. Khaibullin T, Kirillova E, Bikbaev R, et al. Clinical-epidemiological characteristics of multiple sclerosis and neuroopticomyelitis in the Central Asia. Zh Nevrol Psikhiatr Im S S Korsakova 2019;119:12-17.

43. Asgari N, Lillevang ST, Skejoe HPB, et al. Epidemiology of neuromyelitis optica spectrum disorder in Denmark (1998-2008, 2007-2014). Brain Behav 2019;9:e01338.

44. Bove R, Elsone L, Alvarez E, et al. Female hormonal exposures and neuromyelitis optica symptom onset in a multicenter study. Neurol Neuroimmunol Neuroinflamm 2017;4:e339.

45. Hor JY, Asgari N, Nakashima I, et al. Epidemiology of neuromyelitis optica spectrum disorder and its prevalence and incidence worldwide. Front Neurol 2020;11:501

46. Alvarenga M, Schimidt S, Alvarenga RP. Epidemiology of neuromyelitis optica in Latin America. Mult Scler J Exp Transl Clin 2017;3:2055217317730098.

47. Matiello M, Kim HJ, Kim W, et al. Familial neuromyelitis optica. Neurology 2010;75 310-315.

48. Apiwattanakul M, Kasemsuk C. NMO spectrum disorders comprise the major portion of CNS inflammatory diseases in Thai patients: a cross sectional study. Mult Scler Relat Disord 2014;3:61-66.

49. Howlett WP. Inflammatory neurologic disease in sub-Saharan Africa. Neurology 2014;83:656-658

50. Papais-Alvarenga RM, Vasconcelos CCF, Carra A, et al. Central nervous system idiopathic inflammatory demyelinating disorders in South Americans: a descriptive, multicenter, cross-sectional study. PLoS One 2015;10:e0127757.

51. Brill L, Mandel M, Karussis D, et al. Increased occurrence of anti-AQP4 seropositivity and unique HLA Class II associations with neuromyelitis optica (NMO), among Muslim Arabs in Israel. J Neuroimmunol 2016;293:65-70.

52. Mori M, Kuwabara S, Paul F. Worldwide prevalence of neuromyelitis optica spectrum disorders. J Neurol Neurosurg Psychiatry 2018;89:555-556.

53. Waters P, Reindl M, Saiz A, et al. Multicentre comparison of a diagnostic assay: aquaporin-4 antibodies in neuromyelitis optica. J Neurol Neurosurg Psychiatry 2016; 87:1005-1015.

54. Marignier R, Bernard-Valnet R, Giraudon P, et al. Aquaporin-4 antibody-negative neuromyelitis optica: distinct assay sensitivity-dependent entity. Neurology 2013;80: 2194-2200.

55. Waters PJ, McKeon A, Leite MI, et al. Serologic diagnosis of NMO: a multicente comparison of aquaporin-4-IgG assays. Neurology 2012;78:665-671.

56. Fryer JP, Lennon VA, Pittock SJ, et al. AQP4 autoantibody assay performance in clinical laboratory service. Neurol Neuroimmunol Neuroinflamm 2014;1:e11.

57. Juryńczyk M, Weinshenker B, Akman-Demir G, et al. Status of diagnostic approaches to AQP4-IgG seronegative NMO and NMO/MS overlap syndromes. J Neurol 2016; 263:140-149.

58. Zamvil SS, Slavin AJ. Does MOG Ig-positive AQP4-seronegative opticospinal inflammatory disease justify a diagnosis of NMO spectrum disorder? Neurol Neuroimmunol Neuroinflamm 2015;2:e62.

59. Cabre P, Heinzlef O, Merle H, et al. MS and neuromyelitis optica in Martinique (French West Indies). Neurology 2001;56:507-514.

60. Strickland FM, Hewagama A, Lu Q, et al. Environmental exposure, estrogen and two $\mathrm{X}$ chromosomes are required for disease development in an epigenetic model of lupus. J Autoimmun 2012;38:1-20.

61. Yin X, Latif R, Tomer Y, et al. Thyroid epigenetics: $\mathrm{X}$ chromosome inactivation in patients with autoimmune thyroid disease. Ann N Y Acad Sci 2007;1110:193-200.

62. Selmi C, Gershwin ME. Sex and autoimmunity: proposed mechanisms of disease onset and severity. Expert Rev Clin Immunol 2019;15:607-615. 


\section{Neurology}

\section{Worldwide Incidence and Prevalence of Neuromyelitis Optica: A Systematic Review \\ Viktoria Papp, Melinda Magyari, Orhan Aktas, et al.}

Neurology 2021;96;59-77 Published Online before print December 11, 2020

DOI 10.1212/WNL.0000000000011153

\section{This information is current as of December 11, 2020}

\section{Updated Information \&} Services

\section{References}

Subspecialty Collections

Permissions \& Licensing

Reprints including high resolution figures, can be found at: http://n.neurology.org/content/96/2/59.full

This article cites 62 articles, 20 of which you can access for free at: http://n.neurology.org/content/96/2/59.full\#ref-list-1

This article, along with others on similar topics, appears in the following collection(s):

All Demyelinating disease (CNS)

http://n.neurology.org/cgi/collection/all_demyelinating_disease_cns Devic's syndrome

http://n.neurology.org/cgi/collection/devics_syndrome

Incidence studies

http://n.neurology.org/cgi/collection/incidence_studies

Prevalence studies

http://n.neurology.org/cgi/collection/prevalence_studies

Information about reproducing this article in parts (figures,tables) or in its entirety can be found online at:

http://www.neurology.org/about/about_the_journal\#permissions

Information about ordering reprints can be found online:

http://n.neurology.org/subscribers/advertise

Neurology ${ }^{\circledR}$ is the official journal of the American Academy of Neurology. Published continuously since 1951, it is now a weekly with 48 issues per year. Copyright Copyright @ 2020 The Author(s). Published by Wolters Kluwer Health, Inc. on behalf of the American Academy of Neurology.. All rights reserved. Print ISSN: 0028-3878. Online ISSN: 1526-632X.

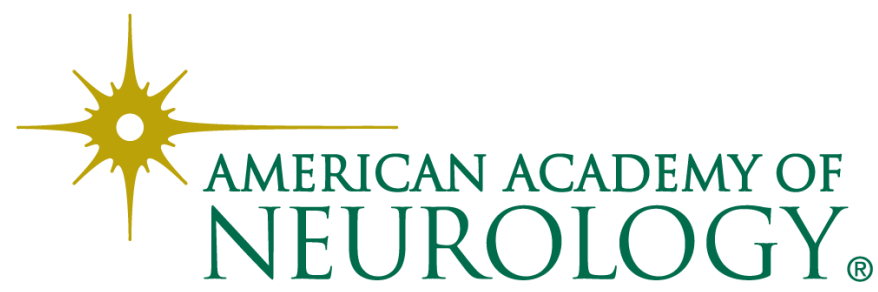

